\title{
LEVEL II SCOUR ANALYSIS FOR BRIDGE 30 (BRNATH00470030) on TOWN HIGHWAY 47, crossing LOCUST CREEK, BARNARD, VERMONT
}

U.S. Geological Survey Open-File Report 97-210

Prepared in cooperation with

VERMONT AGENCY OF TRANSPORTATION and

FEDERAL HIGHWAY ADMINISTRATION 


\section{LEVEL II SCOUR ANALYSIS FOR BRIDGE 30 (BRNATH00470030) on TOWN HIGHWAY 47, crossing LOCUST CREEK, BARNARD, VERMONT}

By ERICK M. BOEHMLER and DONALD L. SONG

U.S. Geological Survey Open-File Report 97-210

Prepared in cooperation with

VERMONT AGENCY OF TRANSPORTATION

and

FEDERAL HIGHWAY ADMINISTRATION 


\title{
U.S. DEPARTMENT OF THE INTERIOR BRUCE BABBITT, Secretary
}

\author{
U.S. GEOLOGICAL SURVEY \\ Gordon P. Eaton, Director
}

For additional information write to:

District Chief

U.S. Geological Survey 361 Commerce Way

Pembroke, NH 03275-3718
Copies of this report may be purchased from:

U.S. Geological Survey

Branch of Information Services

Open-File Reports Unit

Box 25286

Denver, CO 80225-0286 


\section{CONTENTS}

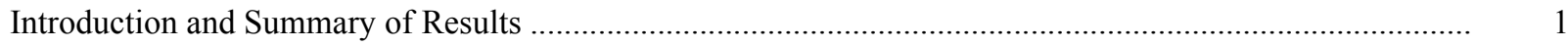

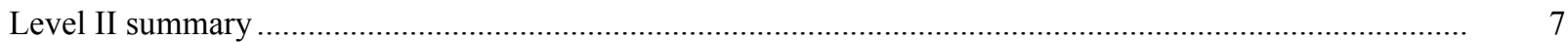

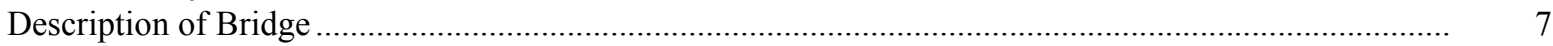

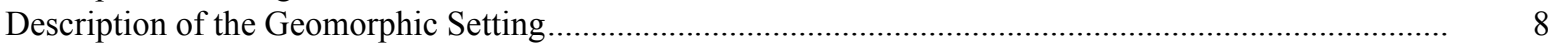

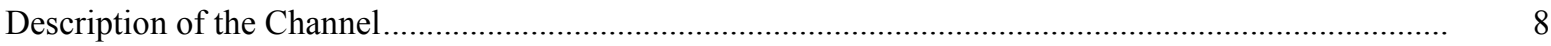

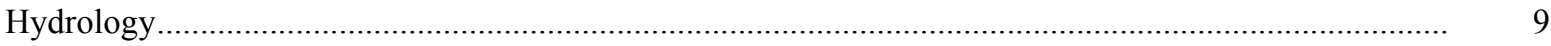

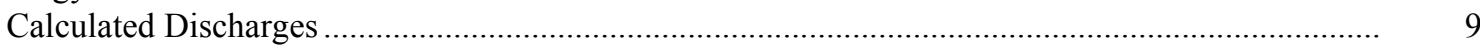

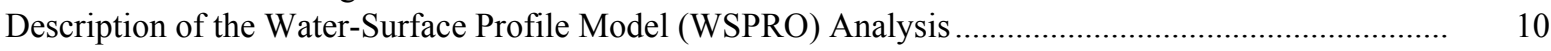

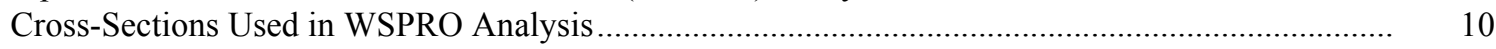

Data and Assumptions Used in WSPRO Model ...................................................................... 11

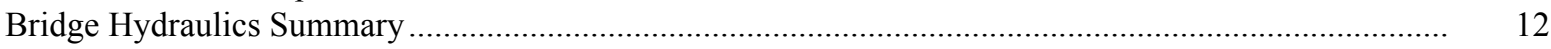

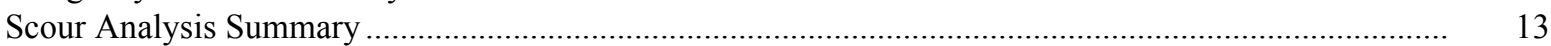

Special Conditions or Assumptions Made in Scour Analysis ...................................................... 13

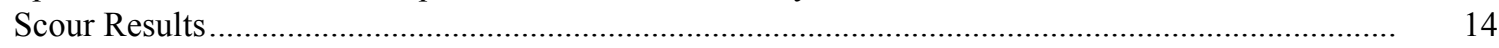

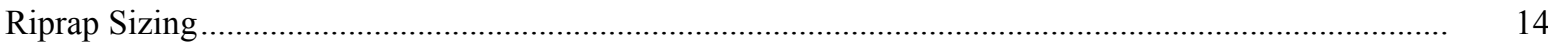

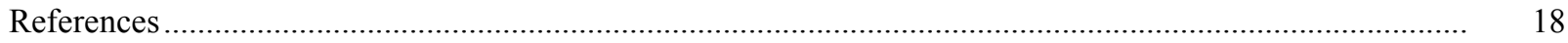

Appendixes:

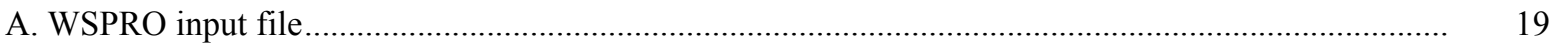

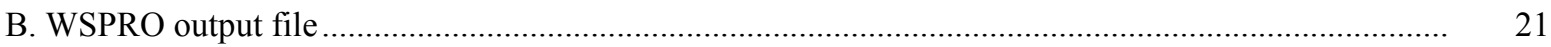

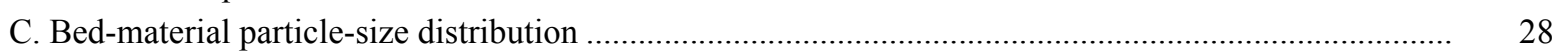

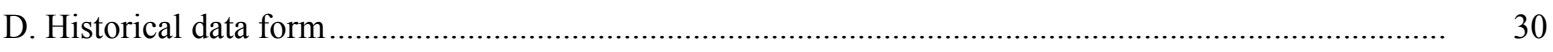

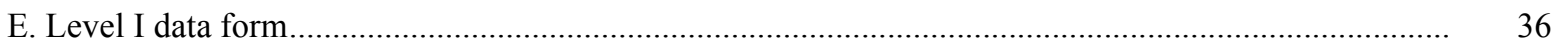

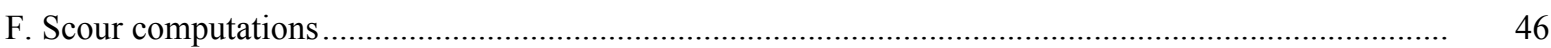

\section{FIGURES}

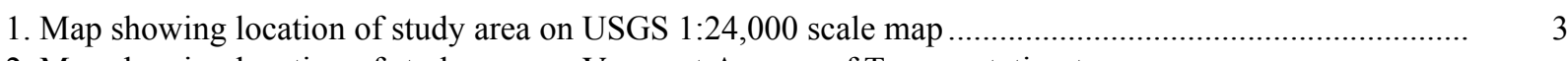

2. Map showing location of study area on Vermont Agency of Transportation town
highway map

3. Structure BRNATH00470030 viewed from upstream (October 13, 1994) ............................................ 5

4. Downstream channel viewed from structure BRNATH00470030 (October 13, 1994). .......................... 5

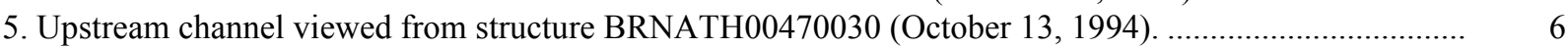

6. Structure BRNATH00470030 viewed from downstream (October 13, 1994)...................................... 6

7. Water-surface profiles for the 100- and 500-year discharges at structure

BRNATH00470030 on Town Highway 47, crossing Locust Creek,

Barnard, Vermont.

8. Scour elevations for the 100- and 500-year discharges at structure

BRNATH00470030 on Town Highway 47, crossing Locust Creek,

Barnard, Vermont.

\section{TABLES}

1. Remaining footing/pile depth at abutments for the 100-year discharge at structure

BRNATH00470030 on Town Highway 47, crossing Locust Creek,

Barnard, Vermont

2. Remaining footing/pile depth at abutments for the 500-year discharge at structure

BRNATH00470030 on Town Highway 47, crossing Locust Creek,

Barnard, Vermont.. 


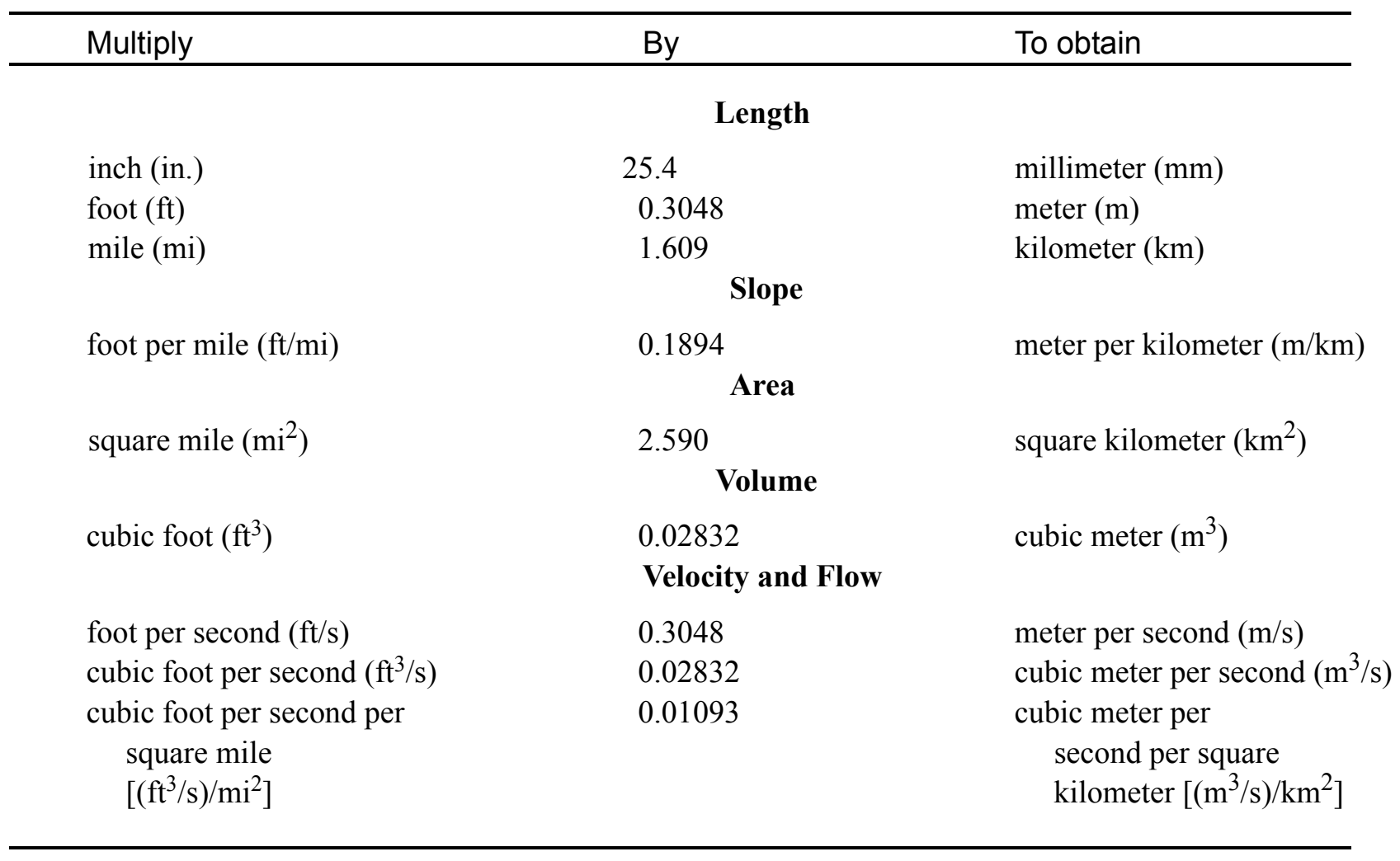

\section{OTHER ABBREVIATIONS}

$\begin{array}{lrlr}\mathrm{BF} & \text { bank full } & \text { LWW } & \text { left wingwall } \\ \mathrm{cfs} & \text { cubic feet per second } & \text { MC } & \text { main channel } \\ \mathrm{D}_{50} & \text { median diameter of bed material } & \text { RAB } & \text { right abutment } \\ \mathrm{DS} & \text { downstream } & \text { RABUT } & \text { face of right abutment } \\ \mathrm{elev} & \text { elevation } & \text { RB } & \text { right bank } \\ \mathrm{f} / \mathrm{p} & \text { flood plain } & \text { ROB } & \text { right overbank } \\ \mathrm{ft}^{2} & \text { square feet } & \text { RWW } & \text { right wingwall } \\ \mathrm{ft} / \mathrm{ft} & \text { feet per foot } & \text { TH } & \text { town highway } \\ \mathrm{JCT} & \text { junction } & \text { UB } & \text { under bridge } \\ \mathrm{LAB} & \text { left abutment } & \text { US } & \text { upstream } \\ \mathrm{LABUT} & \text { face of left abutment } & \text { USGS } & \text { United States Geological Survey } \\ \mathrm{LB} & \text { left bank } & \text { VTAOT Vermont Agency of Transportation } \\ \mathrm{LOB} & \text { left overbank } & \text { WSPRO } & \text { water-surface profile model }\end{array}$

In this report, the words "right" and "left" refer to directions that would be reported by an observer facing downstream. Sea level: In this report, "sea level" refers to the National Geodetic Vertical Datum of 1929-- a geodetic datum derived from a general adjustment of the first-order level nets of the United States and Canada, formerly called Sea Level Datum of 1929.

In the appendices, the above abbreviations may be combined. For example, USLB would represent upstream left bank. 


\title{
LEVEL II SCOUR ANALYSIS FOR BRIDGE 30 (BRNATH00470030) ON TOWN HIGHWAY 47, CROSSING LOCUST CREEK, BARNARD, VERMONT
}

\author{
By Erick M. Boehmler and Donald L. Song
}

\section{INTRODUCTION AND SUMMARY OF RESULTS}

This report provides the results of a detailed Level II analysis of scour potential at structure BRNATH00470030 on Town Highway 47 crossing Locust Creek, Barnard, Vermont (figures 1-8). A Level II study is a basic engineering analysis of the site, including a quantitative analysis of stream stability and scour (U.S. Department of Transportation, 1993). Results of a Level I scour investigation also are included in Appendix E of this report. A Level I investigation provides a qualitative geomorphic characterization of the study site. Information on the bridge, gleaned from Vermont Agency of Transportation (VTAOT) files, was compiled prior to conducting Level I and Level II analyses and is found in Appendix D.

The site is in the Green Mountain section of the New England physiographic province in central Vermont. The $4.18-\mathrm{mi}^{2}$ drainage area is a predominantly rural and forested basin. In the vicinity of the study site, the surface cover consists of trees, shrubs, and brush.

In the study area, Locust Creek has an incised, sinuous channel with a slope of approximately $0.02 \mathrm{ft} / \mathrm{ft}$, an average channel top width of $32 \mathrm{ft}$ and an average bank height of $4 \mathrm{ft}$. The predominant channel bed material is gravel with a median grain size $\left(\mathrm{D}_{50}\right)$ of $49.5 \mathrm{~mm}(0.162 \mathrm{ft})$. The geomorphic assessment at the time of the Level I and Level II site visit on October 13, 1994, indicated that the reach was stable.

The Town Highway 47 crossing of Locust Creek is a 28-ft-long, one-lane bridge consisting of one 25-foot concrete span (Vermont Agency of Transportation, written communication, August 23, 1994). The bridge is supported by vertical, concrete abutments with wingwalls. The channel is skewed approximately 40 degrees to the opening. Historical bridge data indicates that the opening-skew-to-roadway is 45 degrees, but 35 degrees was computed by use of survey data from this study.

A minor scour hole, $0.5 \mathrm{ft}$ deeper than the mean thalweg depth was observed along the left abutment wall during the Level I assessment. The scour protection measures at the site were type- 2 stone fill (less than 36 inches diameter) on the upstream wingwalls. There also is type-3 stone fill on the downstream right wingwall. Additional details describing conditions at the site are included in the Level II Summary and Appendices D and E. 
Scour depths and recommended rock rip-rap sizes were computed using the general guidelines described in Hydraulic Engineering Circular 18 (Richardson and others, 1995). Total scour at a highway crossing is comprised of three components: 1) long-term streambed degradation; 2) contraction scour (due to accelerated flow caused by a reduction in flow area at a bridge) and; 3 ) local scour (caused by accelerated flow around piers and abutments). Total scour is the sum of the three components. Equations are available to compute depths for contraction and local scour and a summary of the results of these computations follows.

Contraction scour for all modelled flows ranged from 0.0 to 1.4 feet. The worst-case contraction scour occurred at the 500-year discharge. Abutment scour ranged from 2.3 to 8.9 feet. The worst-case abutment scour occurred at the 100-year discharge at the right abutment. Additional information on scour depths and depths to armoring are included in the section titled "Scour Results". Scoured-streambed elevations, based on the calculated scour depths, are presented in tables 1 and 2. A cross-section of the scour computed at the bridge is presented in figure 8. Scour depths were calculated assuming an infinite depth of erosive material and a homogeneous particle-size distribution.

It is generally accepted that the Froehlich equation (abutment scour) gives "excessively conservative estimates of scour depths" (Richardson and others, 1995, p. 47). Usually, computed scour depths are evaluated in combination with other information including (but not limited to) historical performance during flood events, the geomorphic stability assessment, existing scour protection measures, and the results of the hydraulic analyses. Therefore, scour depths adopted by VTAOT may differ from the computed values documented herein. 


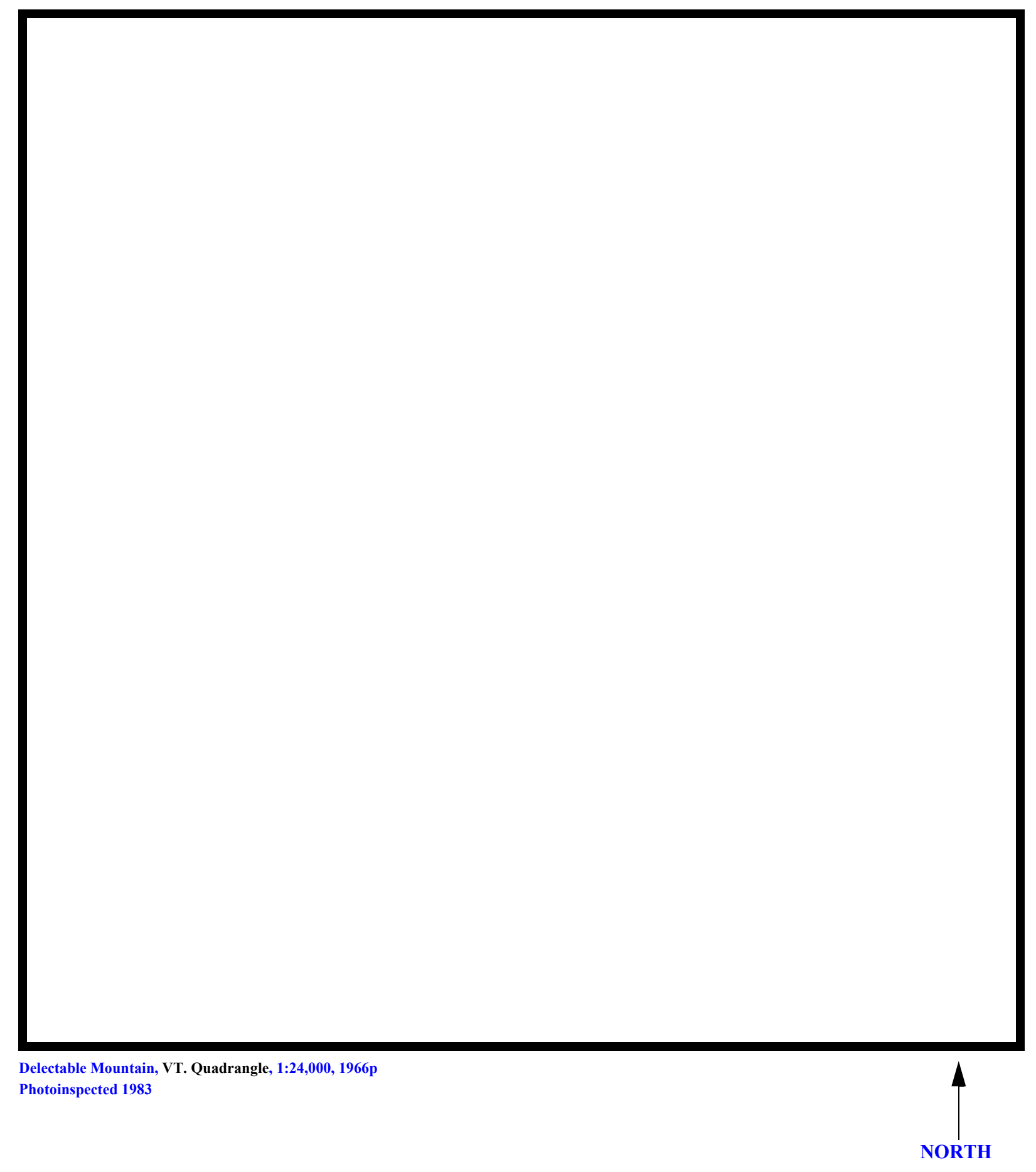

Figure 1. Location of study area on USGS 1:24,000 scale map. 
Figure 2. Location of study area on Vermont Agency of Transportation town highway map. 

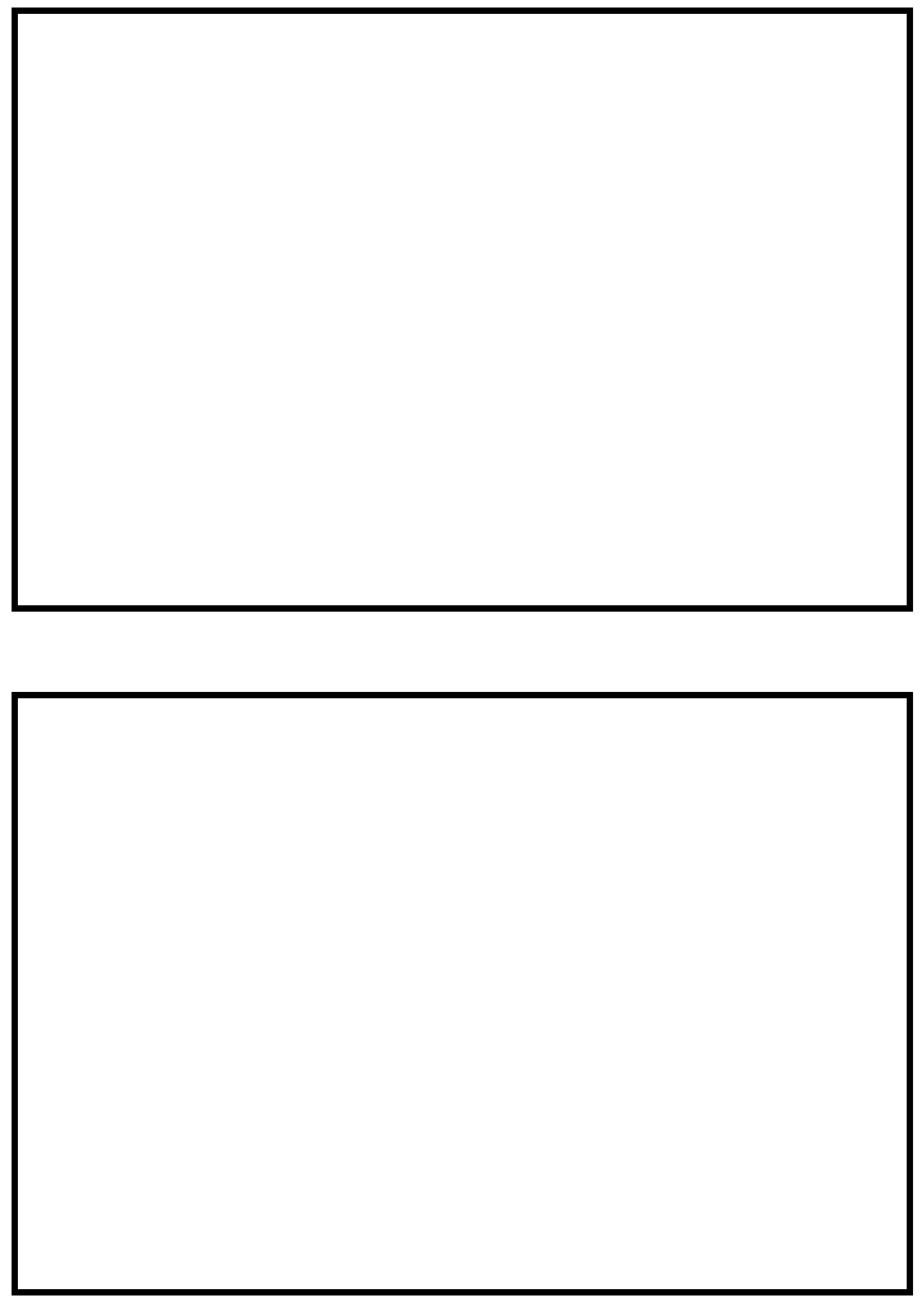

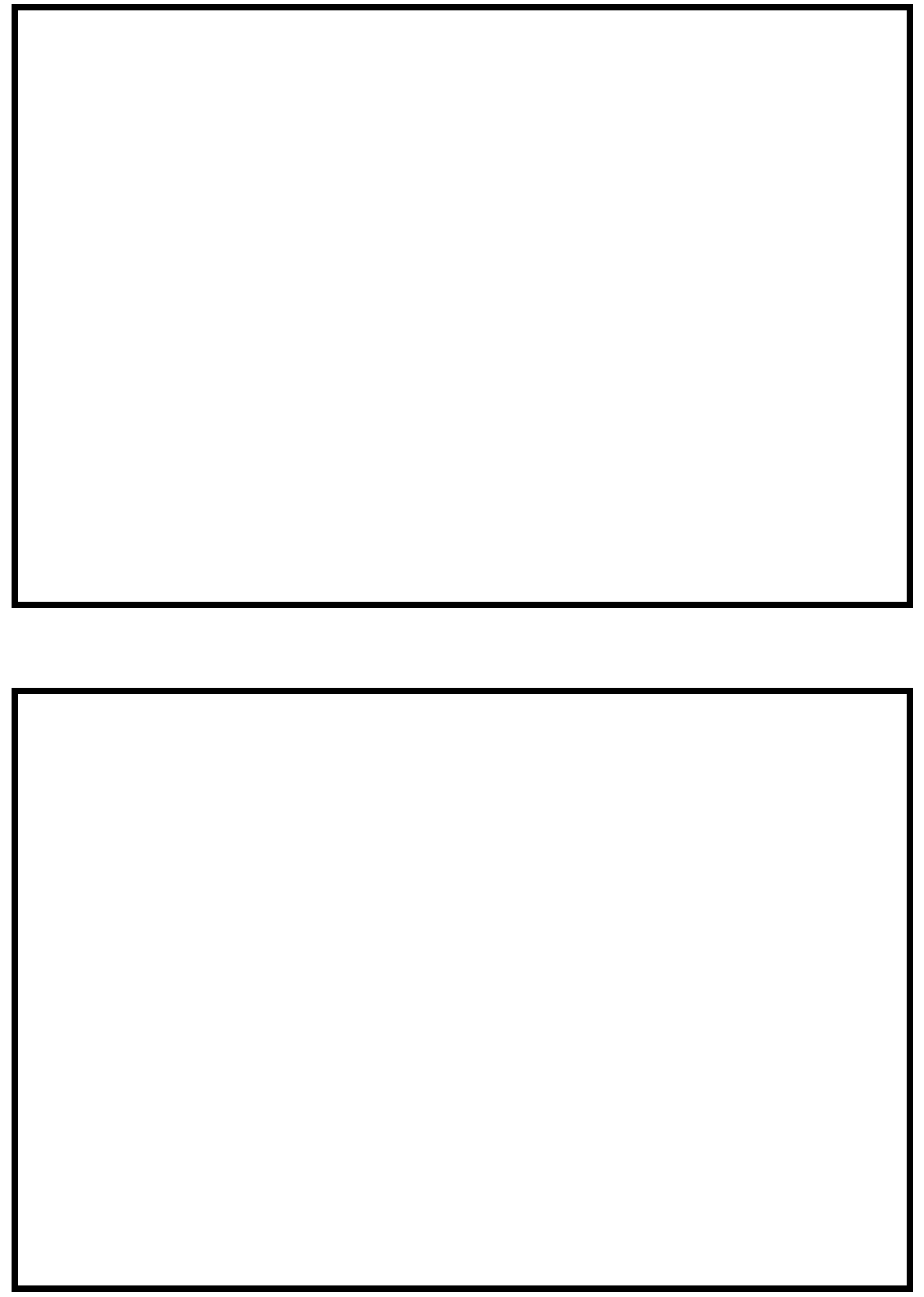


\section{LEVEL II SUMMARY}

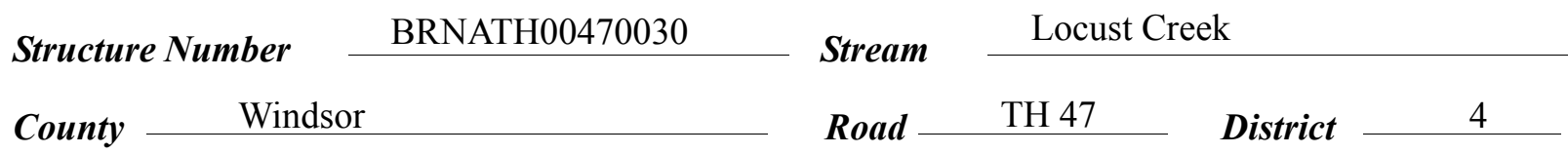

\section{Description of Bridge}

Bridge length $\frac{28}{2} \boldsymbol{f t}$ Bridge width $\frac{15.5}{f t}$ Max span length $\frac{25}{f t}$

Alignment of bridge to road (on curve or straight)

Vertical, concrete

Abutment type

Stone fill on abutment?

\section{Embankment type}

$$
\text { No }
$$

Straight

$$
\text { Sloping right; none left }
$$

nacamintinu af atan a fill Type-2 along the base of the upstream wingwalls. Type-3 stone fill was present on the downstream right wingwall.

Abutments and wingwalls are concrete. There is a one

half foot deep scour hole along the left abutment.

$$
\text { Yes }
$$

\section{Is bridge skewed to flood flow according to Yes 'survey? Angle}

There is a mild channel bend immediately upstream of the bridge. The sçour hole has deyeloped in

\begin{tabular}{|c|c|c|c|}
\hline & $\begin{array}{c}\text { Date of incnortion } \\
10 / 13 / 94 \\
\end{array}$ & $\begin{array}{l}\text { Percent of ahmmont } \\
\text { bloeked inortzontatly }\end{array}$ & $\begin{array}{l}\text { Percent of } 0 \\
\text { blocked verticatty }\end{array}$ \\
\hline ovel I & $10 / 13 / 94$ & 0 & 0 \\
\hline
\end{tabular}
the same location where the bend occurs.

Debris accumulation on bridge at time of Level I or Level II site visit:

Level II

Moderate. There is significant vegetation growth on channel banks that have been undermined and eroded.

Potential for debris

None evident on 10/13/94.

Dosrriho anv foaturos noar ar at tho hridoo that mav, affort flow, (includo ahsorvation dato). 


\section{Description of the Geomorphic Setting}

General topography The channel is located in a moderate relief valley setting with narrow, irregular overbank areas and steep valley walls on both sides.

Geomorphic conditions at bridge site: downstream (DS), upstream (US)

Date of inspection $\quad 10 / 13 / 94$

DS left: $\quad$ Moderately sloping channel bank to a narrow overbank.

DS right: $\quad$ Mildly sloping channel bank to a narrow overbank.

US left: $\quad$ Steep channel bank to valley wall

US right: $\quad$ Steep channel bank to a narrow overbank

\section{Description of the Channel}

$\begin{array}{llll}\text { Average top width } & 32 & \text { Average depth } & 4 \\ & \text { Gravel } & \boldsymbol{f}\end{array}$

Predominant bed material

Bank material

with semi-allúvial channel boundaries.

Sinuous but stable

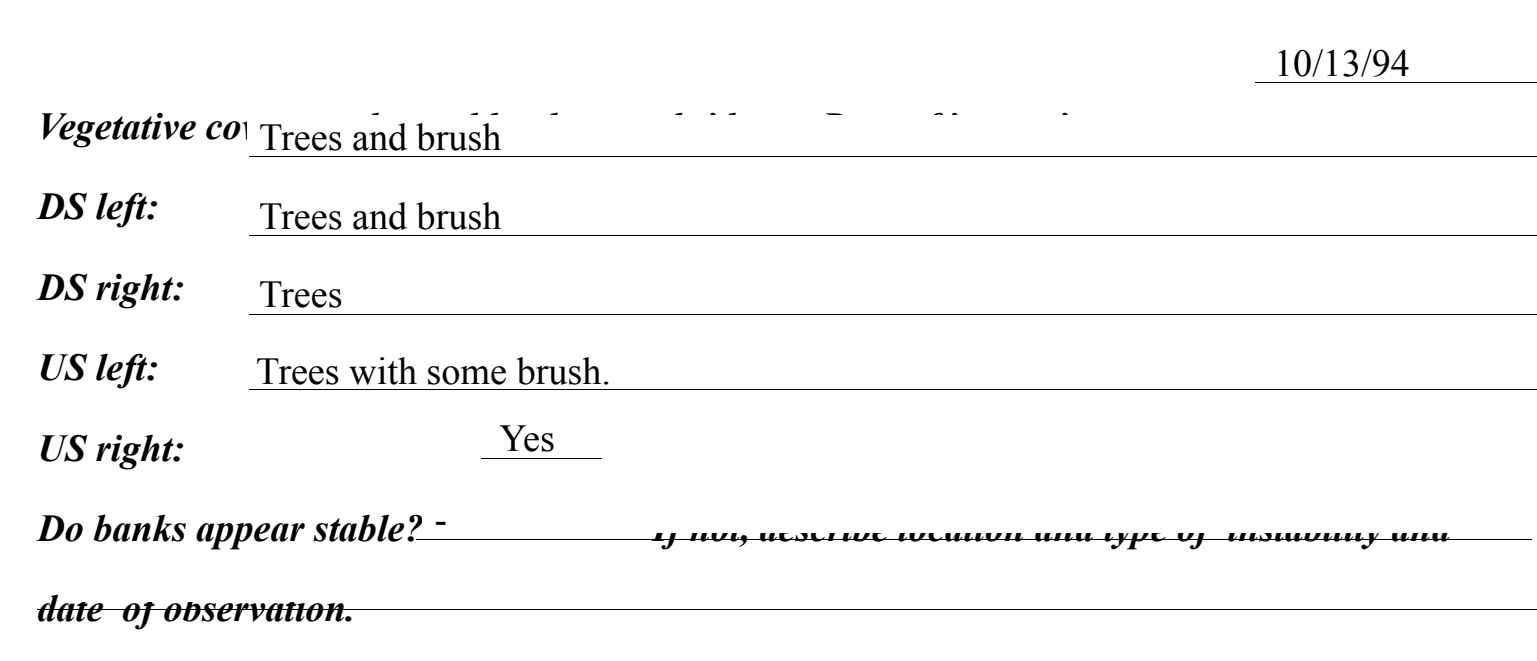

None were noted in the

assessment of 10/13/94.

Describe any obstructions in channel and date of observation. 


\section{Hydrology}

Drainage area $\stackrel{4.18}{m^{2}}{ }^{2}$

Percentage of drainage area in physiographic provinces: (approximate)

Physiographic province/section

New England / Green Mountain
Percent of drainage area 100

Is drainage area considered rural or urban? — Rural _ Describe any significant urbanization:

Is there a USGS gage on the stream of interest?

No

USGS gage description

USGS gage number

Gage drainage area $\mathrm{mi}^{2}$ $m i^{2}$ No

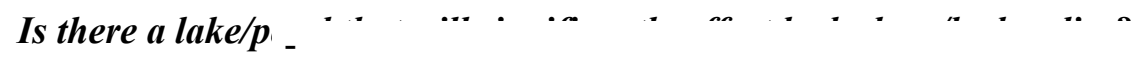

Q100 $\quad \mathrm{ft}^{3} / \mathrm{s} \quad \mathrm{Q500} \quad \mathrm{ft} / \mathrm{s}$

The 100- and 500-year discharges are based on flood

frequency estimates available in the VTAOT database. These values were selected from within a range of flood frequency curves defined by several empirical equations (Benson, 1962; FHWA, 1983; Johnson and Laraway, unpublished draft, 1972; Johnson and Tasker, 1974; Potter, 1957 $\mathrm{a} \& \mathrm{~b}$; and Talbot, 1887). 


\section{Description of the Water-Surface Profile Model (WSPRO) Analysis}

Datum for WSPRO analysis (USGS survey, sea level, VTAOT plans)

USGS survey

Datum tie between USGS survey and VTAOT plans

Add 2.1 feet to the USGS

arbitrary survey datum to obtain the VTAOT plans' datum.

Description of reference marks used to determine USGS datum. $\quad$ RM1 is the center point

of a chiseled "X" on top of the upstream end of the left abutment (elev. 499.57 feet, arbitrary

survey datum). RM2 is the center point of a chiseled " $\mathrm{X}$ " on top of the downstream end of the

left abutment (elev. 499.61 feet, arbitrary survey datum).

\section{Cross-Sections Used in WSPRO Analysis}

\begin{tabular}{cccl}
\hline${ }^{1}$ Cross-section & $\begin{array}{c}\text { Section } \\
\text { Reference } \\
\text { Distance } \\
\text { (SRD) in feet }\end{array}$ & $\begin{array}{c}{ }^{2} \text { Cross-section } \\
\text { development }\end{array}$ & \multicolumn{1}{c}{ Comments } \\
\hline EXITX & -36 & 1 & Exit section \\
FULLV & 0 & 2 & $\begin{array}{l}\text { Downstream Full-valley } \\
\text { section (Templated from } \\
\text { EXITX) }\end{array}$ \\
BRIDG & 0 & 1 & $\begin{array}{l}\text { Bridge section } \\
\text { Road Grade section } \\
\text { RDWAY }\end{array}$ \\
APPRO & 12 & 1 & Approach section \\
\hline
\end{tabular}

${ }^{1}$ For location of cross-sections see plan-view sketch included with Level I field form, Appendix E. For more detail on how cross-sections were developed see WSPRO input file. 


\section{Data and Assumptions Used in WSPRO Model}

Hydraulic analyses of the reach were done by use of the Federal Highway Administration's WSPRO step-backwater computer program (Shearman and others, 1986, and Shearman, 1990). The analyses reported herein reflect conditions existing at the site at the time of the study. Furthermore, in the development of the model it was necessary to assume no accumulation of debris or ice at the site. Results of the hydraulic model are presented in the Bridge Hydraulic Summary, Appendix B, and figure 7.

Channel roughness factors (Manning's " $n$ ") used in the hydraulic model were estimated using field inspections at each cross section following the general guidelines described by Arcement and Schneider (1989). Final adjustments to the values were made during the modelling of the reach. Channel " $\mathrm{n}$ " values for the reach ranged from 0.055 to 0.065 , and overbank " $\mathrm{n}$ " values ranged from 0.030 to 0.075 .

Normal depth at the exit section (EXITX) was assumed as the starting water surface. This depth was computed by use of the slope-conveyance method outlined in the user's manual for WSPRO (Shearman, 1990). The slope used was $0.0171 \mathrm{ft} / \mathrm{ft}$, which was estimated from surveyed points downstream of the bridge.

The approach section (APPRO) was surveyed at one bridge length upstream of the upstream face as recommended by Shearman and others (1986). This location also provides a consistent method for determining scour variables.

For the incipient overtopping discharge, WSPRO assumes critical depth at the bridge section. A supercritical model was developed for this discharge. After analyzing both the supercritical and subcritical profiles, it was determined that the water surface profile passes through critical depth within the bridge opening. Thus, the assumption of critical depth at the bridge is a satisfactory solution. 


\section{Bridge Hydraulics Summary}

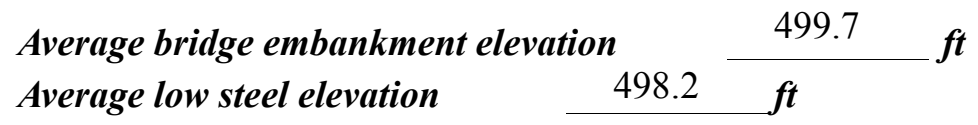

$$
\text { 100-year discharge } \quad 1,150 \quad \mathrm{ft}^{3} / \mathrm{s}
$$

Water-surface elevation in bridge opening $\quad 498.2 \quad f t$

Road overtopping? ___ Yes Discharge over road ___ $\quad \mathrm{ft}^{3} / \mathrm{s}$

\begin{tabular}{llll} 
Area of flow in bridge opening & $135 \quad \mathrm{ft}^{2}$ & \\
\cline { 2 - 3 } Average velocity in bridge opening & 7.9 & $\mathrm{ft} / \mathrm{s}$
\end{tabular}

$\begin{array}{llll}\text { Maximum WSPRO tube velocity at bridge } & 9.5 \mathrm{ft} / \mathrm{s}\end{array}$

Water-surface elevation at Approach section with bridge 499.8

Water-surface elevation at Approach section without bridge $\quad 496.5$

Amount of backwater caused by bridge $\quad 3.3$ it

500-year discharge $\quad 1,540 \quad \mathrm{ft}^{3} / \mathrm{s}$

Water-surface elevation in bridge opening $\quad 498.2 \mathrm{ft}$

Road overtopping? ____ Yes Discharge over road __ $345 \quad \mathrm{ft}^{3} / \mathrm{s}$

$\begin{array}{llll}\text { Area of flow in bridge opening } & 135 & \boldsymbol{f t}^{2} & \\ \text { Average velocity in bridge opening } & & 8.8 \quad \mathrm{ft} / \mathrm{s}\end{array}$

Maximum WSPRO tube velocity at bridge 11.9 /

Water-surface elevation at Approach section with bridge 500.3

Water-surface elevation at Approach section without bridge $\quad 496.9$

Amount of backwater caused by bridge $\quad 3.4$.

Incipient overtopping discharge $\quad 989 \quad \mathrm{ft}^{3} / \mathrm{s}$

Water-surface elevation in bridge opening $495.5 \quad t$

Area of flow in bridge opening

Average velocity in bridge opening

$83 \boldsymbol{f t}^{2}$

Maximum WSPRO tube velocity at bridge $\quad 14.8 \mathrm{ft} / \mathrm{s}$

Water-surface elevation at Approach section with bridge

Water-surface elevation at Approach section without bridge

498.9

Amount of backwater caused by bridge $\quad 2.7$, t

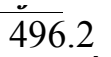




\section{Scour Analysis Summary}

\section{Special Conditions or Assumptions Made in Scour Analysis}

Scour depths were computed using the general guidelines described in Hydraulic Engineering Circular 18 (Richardson and others, 1995). Scour depths were calculated assuming an infinite depth of erosive material and a homogeneous particle-size distribution. The results of the scour analysis are presented in tables 1 and 2 and a graph of the scour depths is presented in figure 8 .

Contraction scour for the incipient overtopping discharge was computed by use of the clear-water contraction scour equation (Richardson and others, 1995, p. 32, equation 20). The 100- and 500-year discharges resulted in unsubmerged orifice flow. Contraction scour at bridges with orifice flow is best estimated by use of the Chang pressure-flow scour equation (oral communication, J. Sterling Jones, October 4, 1996). Thus, the reported contraction scour for the 100- and 500-year events were computed by use of the Chang equation (Richardson and others, 1995, P. 145-146). Results from the Chang equation are shown in figure 8 and tables 1 and 2. The results of Laursen's clear-water contraction scour for the 100- and 500-year events also were computed and are provided in appendix F. The streambed armoring depths computed suggest that armoring will not limit the depth of contraction scour.

Abutment scour was computed by use of the Froehlich equation (Richardson and others, 1995, p. 48, equation 28). Variables for the Froehlich equation include the Froude number of the flow approaching the embankments, the length of the embankment blocking flow, and the depth of flow approaching the embankment less any roadway overtopping. 


\section{Scour Results}

$$
\text { 100-yr discharge 500-yr discharge }
$$

Contraction scour:

Main channel

Live-bed scour

Clear-water scour

Depth to armoring

Left overbank

Right overbank

Local scour:

Abutment scour

Left abutment

Right abutment

Pier scour

Pier 1

Pier 2

Pier 3
(Scour depths in feet) discharge

Incipient overtopping 


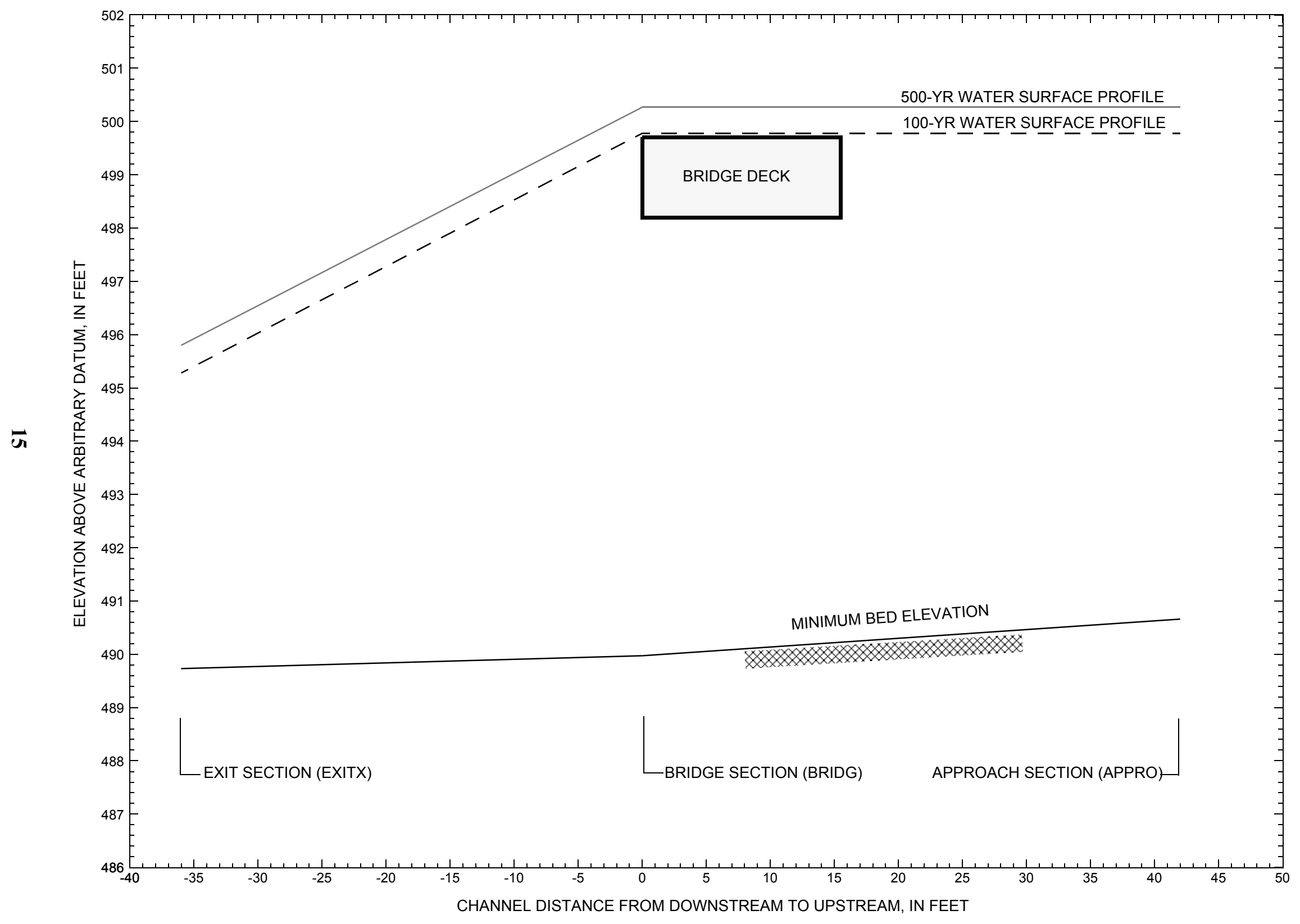

Figure 7. Water-surface profiles for the 100- and 500-yr discharges at structure BRNATH00470030 on Town Highway 47, crossing Locust Creek, Barnard, Vermont. 


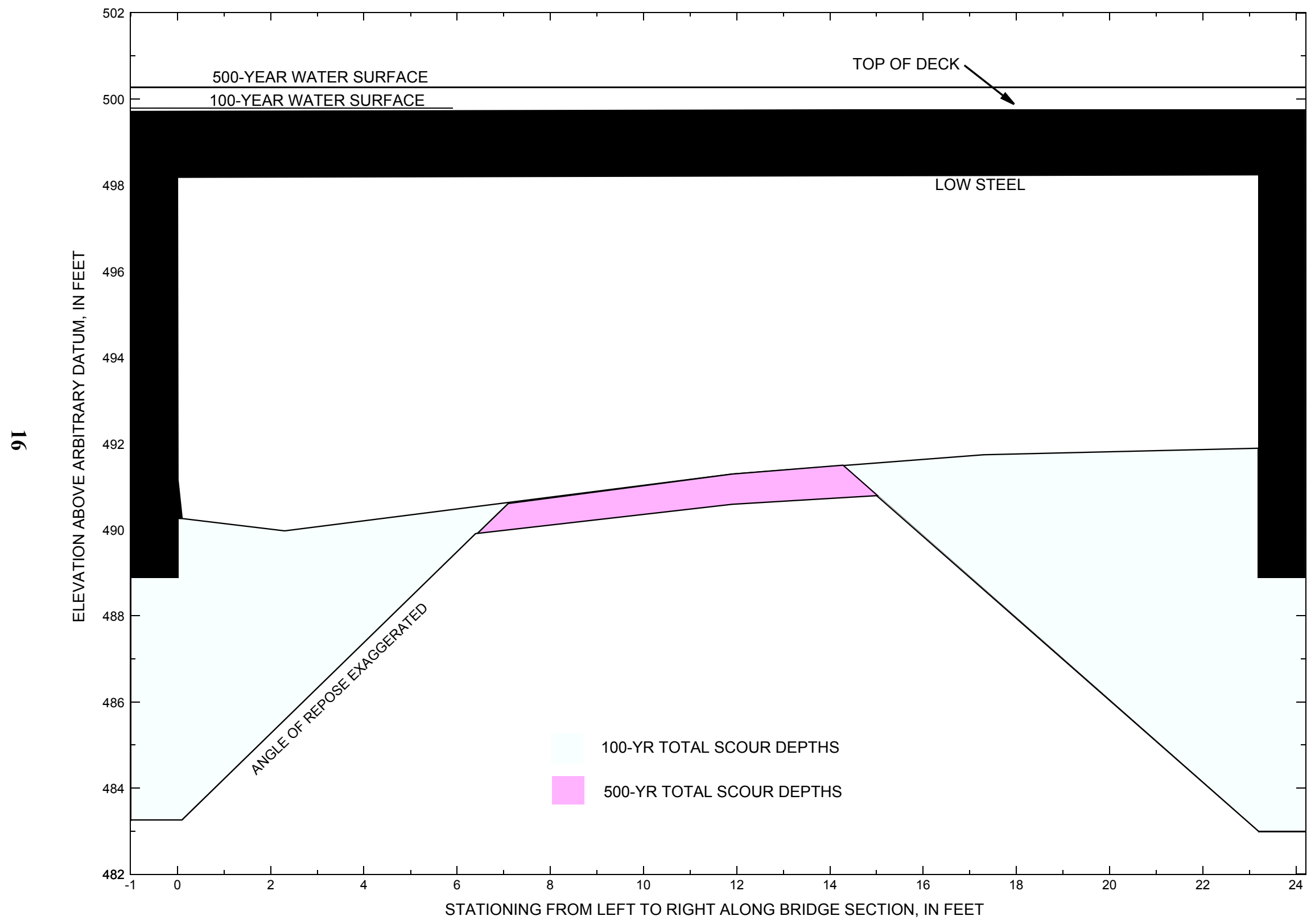

Figure 8. Scour elevations for the 100-yr and 500-yr discharges at structure BRNATH00470030 on Town Highway 47, crossing Locust Creek, Barnard, Vermont. 
Table 1. Remaining footing/pile depth at abutments for the 100-year discharge at structure BRNATH00470030 on Town Highway 47, crossing Locust Creek, Barnard, Vermont.

[VTAOT, Vermont Agency of Transportation; --,no data]

\begin{tabular}{|c|c|c|c|c|c|c|c|c|c|c|c|}
\hline Description & Station $^{1}$ & $\begin{array}{c}\text { VTAOT } \\
\text { bridge seat } \\
\text { elevation } \\
\text { (feet) }\end{array}$ & $\begin{array}{c}\text { Surveyed } \\
\text { minimum } \\
\text { low-chord } \\
\text { elevation }{ }^{2} \\
\text { (feet) }\end{array}$ & $\begin{array}{c}\text { Bottom of } \\
\text { footing } \\
\text { elevation } \\
\text { (feet) }\end{array}$ & $\begin{array}{c}\text { Channel } \\
\text { elevation at } \\
\text { abutment/ } \\
\text { pier }^{2} \\
\text { (feet) }\end{array}$ & $\begin{array}{l}\text { Contraction } \\
\text { scour depth } \\
\text { (feet) }\end{array}$ & $\begin{array}{l}\text { Abutment } \\
\text { scour } \\
\text { depth } \\
\text { (feet) }\end{array}$ & $\begin{array}{l}\text { Pier } \\
\text { scour } \\
\text { depth } \\
\text { (feet) }\end{array}$ & $\begin{array}{l}\text { Depth of } \\
\text { total scour } \\
\text { (feet) }\end{array}$ & $\begin{array}{c}\text { Elevation of } \\
\text { scour }^{2} \\
\text { (feet) }\end{array}$ & $\begin{array}{c}\text { Remaining } \\
\text { footing/pile } \\
\text { depth } \\
\text { (feet) }\end{array}$ \\
\hline \multicolumn{12}{|c|}{100 -yr. discharge is 1,150 cubic-feet per second } \\
\hline Left abutment & 0.0 & 500.3 & 498.2 & 488.9 & 490.3 & 0.0 & 7.0 & -- & 7.0 & 483.3 & -5.6 \\
\hline Right abutment & 23.2 & 500.3 & 498.2 & 488.9 & 491.9 & 0.0 & 8.9 & -- & 8.9 & 483.0 & -5.9 \\
\hline
\end{tabular}

1.Measured along the face of the most constricting side of the bridge.

2.Arbitrary datum for this study.

Table 2. Remaining footing/pile depth at abutments for the 500-year discharge at structure BRNATH00470030 on Town Highway 47, crossing Locust Creek, Barnard, Vermont.

[VTAOT, Vermont Agency of Transportation; --, no data]

\begin{tabular}{|c|c|c|c|c|c|c|c|c|c|c|c|}
\hline Description & Station $^{1}$ & $\begin{array}{l}\text { VTAOT } \\
\text { bridge seat } \\
\text { elevation } \\
\text { (feet) }\end{array}$ & $\begin{array}{c}\text { Surveyed } \\
\text { minimum } \\
\text { low-chord } \\
\text { elevation } \\
\text { (feet) }\end{array}$ & $\begin{array}{c}\text { Bottom of } \\
\text { footing } \\
\text { elevation } \\
\text { (feet) }\end{array}$ & $\begin{array}{c}\text { Channel } \\
\text { elevation at } \\
\text { abutment/ } \\
\text { pier }^{2} \\
\text { (feet) }\end{array}$ & $\begin{array}{l}\text { Contraction } \\
\text { scour depth } \\
\text { (feet) }\end{array}$ & $\begin{array}{l}\text { Abutment } \\
\text { scour } \\
\text { depth } \\
\text { (feet) }\end{array}$ & $\begin{array}{l}\text { Pier } \\
\text { scour } \\
\text { depth } \\
\text { (feet) }\end{array}$ & $\begin{array}{l}\text { Depth of } \\
\text { total scour } \\
\text { (feet) }\end{array}$ & $\begin{array}{c}\text { Elevation of } \\
\text { scour }^{2} \\
\text { (feet) }\end{array}$ & $\begin{array}{c}\text { Remaining } \\
\text { footing/pile } \\
\text { depth } \\
\text { (feet) }\end{array}$ \\
\hline \multicolumn{12}{|c|}{500 -yr. discharge is 1,540 cubic-feet per second } \\
\hline Left abutment & 0.0 & 500.3 & 498.2 & 488.9 & 490.3 & 0.7 & 5.1 & -- & 5.8 & 484.5 & -4.4 \\
\hline Right abutment & 23.2 & 500.3 & 498.2 & 488.9 & 491.9 & 0.7 & 2.3 & -- & 3.0 & 488.9 & 0.0 \\
\hline
\end{tabular}

1.Measured along the face of the most constricting side of the bridge.

2.Arbitrary datum for this study. 


\section{SELECTED REFERENCES}

Arcement, G.J., Jr., and Schneider, V.R., 1989, Guide for selecting Manning's roughness coefficients for natural channels and flood plains:

U.S. Geological Survey Water-Supply Paper 2339, 38 p.

Barnes, H.H., Jr., 1967, Roughness characteristics of natural channels: U.S. Geological Survey Water-Supply Paper 1849,213 p.

Benson, M. A., 1962, Factors Influencing the Occurrence of Floods in a Humid Region of Diverse Terrain: U.S. Geological Survey WaterSupply Paper 1580-B, 64 p.

Brown, S.A. and Clyde, E.S., 1989, Design of riprap revetment: Federal Highway Administration Hydraulic Engineering Circular No. 11, Publication FHWA-IP-89-016, 156 p.

Federal Highway Administration, 1983, Runoff estimates for small watersheds and development of sound design: Federal Highway Administration Report FHWA-RD-77-158

Froehlich, D.C., 1989, Local scour at bridge abutments in Ports, M.A., ed., Hydraulic Engineering--Proceedings of the 1989 National Conference on Hydraulic Engineering: New York, American Society of Civil Engineers, p. 13-18.

Hayes, D.C.,1993, Site selection and collection of bridge-scour data in Delaware, Maryland, and Virginia: U.S. Geological Survey WaterResources Investigation Report 93-4017, 23 p.

Johnson, C.G. and Tasker, G.D.,1974, Progress report on flood magnitude and frequency of Vermont streams: U.S. Geological Survey OpenFile Report 74-130, 37 p.

Lagasse, P.F., Schall, J.D., Johnson, F., Richardson, E.V., Chang, F., 1995, Stream Stability at Highway Structures: Federal Highway Administration Hydraulic Engineering Circular No. 20, Publication FHWA-IP-90-014, 144 p.

Laursen, E.M., 1960, Scour at bridge crossings: Journal of the Hydraulics Division, American Society of Civil Engineers, v. 86, no. HY2, p. 39-53.

Potter, W. D., 1957a, Peak rates of runoff in the Adirondack, White Mountains, and Maine woods area, Bureau of Public Roads

Potter, W. D., 1957b, Peak rates of runoff in the New England Hill and Lowland area, Bureau of Public Roads

Richardson, E.V. and Davis, S.R., 1995, Evaluating scour at bridges: Federal Highway Administration Hydraulic Engineering Circular No. 18, Publication FHWA-IP-90-017, 204 p.

Richardson, E.V., Simons, D.B., and Julien, P.Y., 1990, Highways in the river environment: Federal Highway Administration Publication FHWA-HI-90-016.

Ritter, D.F., 1984, Process Geomorphology: W.C. Brown Co., Debuque, Iowa, 603 p.

Shearman, J.O., 1990, User's manual for WSPRO--a computer model for water surface profile computations: Federal Highway Administration Publication FHWA-IP-89-027, 187 p.

Shearman, J.O., Kirby, W.H., Schneider, V.R., and Flippo, H.N., 1986, Bridge waterways analysis model; research report: Federal Highway Administration Publication FHWA-RD-86-108, 112 p.

Talbot, A.N., 1887, The determination of water-way for bridges and culverts.

U.S. Department of Transportation, 1993, Stream stability and scour at highway bridges, Participant Workbook: Federal Highway Administration Publication FHWA HI-91-011.

U.S. Geological Survey, 1966, Delectable Mountain, Vermont 7.5 Minute Series quadrangle map: U.S. Geological Survey Topographic Maps, Aerial photographs, 1964; Photoinspected 1983, Contour interval, 20 feet; Scale 1:24,000. 


\section{APPENDIX A: \\ WSPRO INPUT FILE}




\section{WSPRO INPUT FILE}

GR

GR

GR

GR

GR

*

$\mathrm{N}$

SA

*

X

BR

*

GR

GR

GR

*

$\mathrm{CD}$

$\mathrm{N}$

*

XR

GR

GR

GR

*

AS

GR

GR

GR

GR

*

$\mathrm{N}$

SA

HP 1 BRIDG

HP 2 BRIDG

HP 2 RDWAY

HP 1 APPRO

HP 2 APPRO

*

HP 1 BRIDG

HP 2 BRIDG

HP 2 RDWAY

HP 1 APPRO
U.S. GEOLOGICAL SURVEY WSPRO INPUT FILE brna030.wsp CREATED ON 13-DEC-95 FOR BRIDGE BRNATH00470030 USING FILE brna030.dca Town Highway 47 Bridge Over Locust Creek, Barnard, VT EMB $1150.0 \quad 1540.0 \quad 989.0$ $0.0171 \quad 0.0171 \quad 0.0171$

* * 0.005

$\begin{array}{lllllllllllllllllllll}6 & 29 & 30 & 552 & 553 & 551 & 5 & 16 & 17 & 13 & 3 & * & 15 & 14 & 23 & 21 & 11 & 12 & 4 & 7 & 3\end{array}$

0 .

$\begin{array}{rrrrr}-99.7,504.29 & -80.6,501.69 & -56.0,499.16 & -40.9,499.00 \\ -26.1,495.00 & -11.5,495.13 & -7.0,493.83 & 0.0,490.58 \\ 3.0,490.21 & 5.0,489.73 & 10.0,490.09 & 12.5,490.65 \\ 17.0,490.52 & 24.4,491.96 & 38.4,494.52 & 64.8,495.30 \\ 70.8,499.29 & 84.1,499.79 & 99.0,507.77 & & \end{array}$

$$
\begin{array}{llllll}
0.030 & -40.9 & 0.060 & 0.065 & 0.060
\end{array}
$$

0.0171

35.0

$$
0.0,498.18
$$

$0.0,491.16$

$0.1,490.26$

$2.3,489.97$

$6.0,490.46$

$11.9,491.29$

$17.3,491.74$

$23.2,491.89$

$23.2,498.24$

$0.0,498.18$

423.0

6.1

500.0

39.8

0.0

0.055

$\begin{array}{lll}12 & 15.5 & 2\end{array}$

$-90.7,504.29$

$-75.5,501.69$

$-53.9,499.16$

$0.0,499.71$

$27.5,499.77$

$50.3,500.14$

$95.6,500.79$

$100.1,501.35$

$116.6,508.07$

420.0

$\begin{array}{rr}-36.2, & 509.72 \\ -4.6, & 497.91 \\ 19.0, & 491.95 \\ 79.3, & 500.93\end{array}$

$-20.2,497.98$

$-12.9,498.25$

$-6.9,498.58$

$0.0,492.04$

$7.0,490.66$

$9.8,491.11$

$79.3,500.93$

$26.4,500.01$

$39.0,500.04$

$52.9,500.07$

0.075

$-6.9$

0.065

$118.4,508.07$

498.241498 .24

$498.24 \star * 1071$

499.78 * 74

$499.78 \quad 1499.78$

499.78 * * 1150

498.201498 .20

$498.20 * * 1194$

500.27 * *345

500.271500 .27 


\section{APPENDIX B: \\ WSPRO OUTPUT FILE}




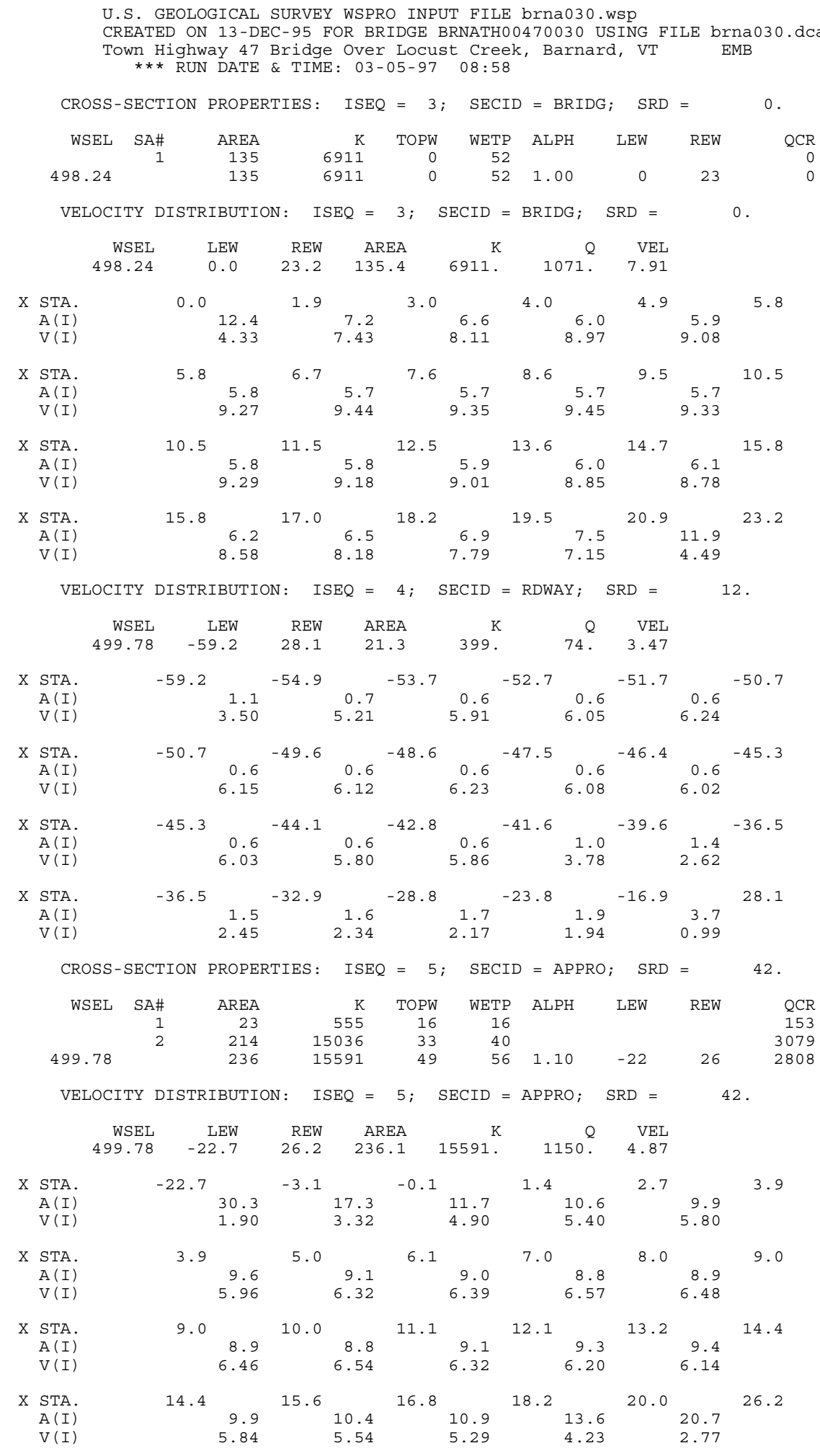


WSPRO OUTPUT FILE (continued)

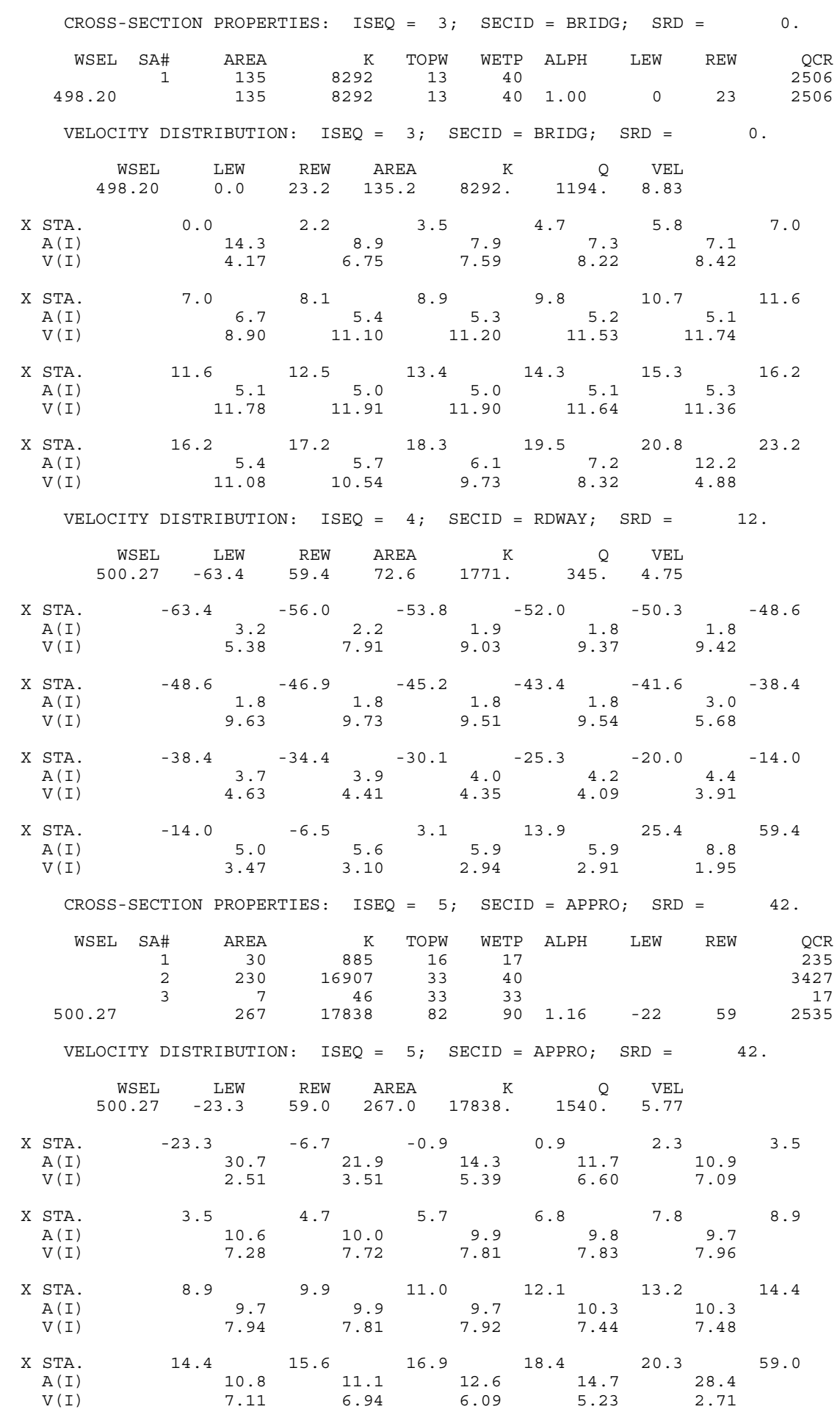


WSPRO OUTPUT FILE (continued)

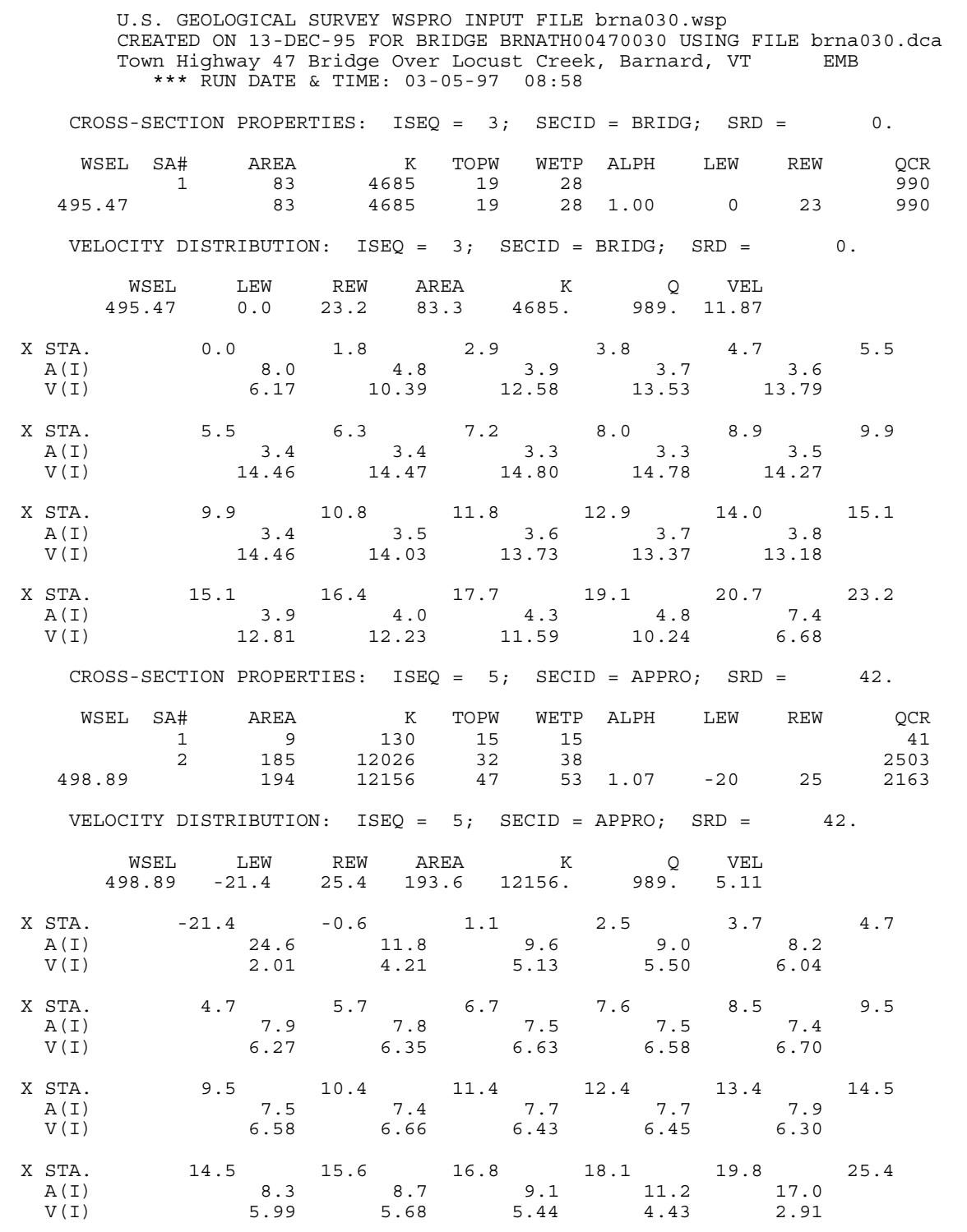


WSPRO OUTPUT FILE (continued)

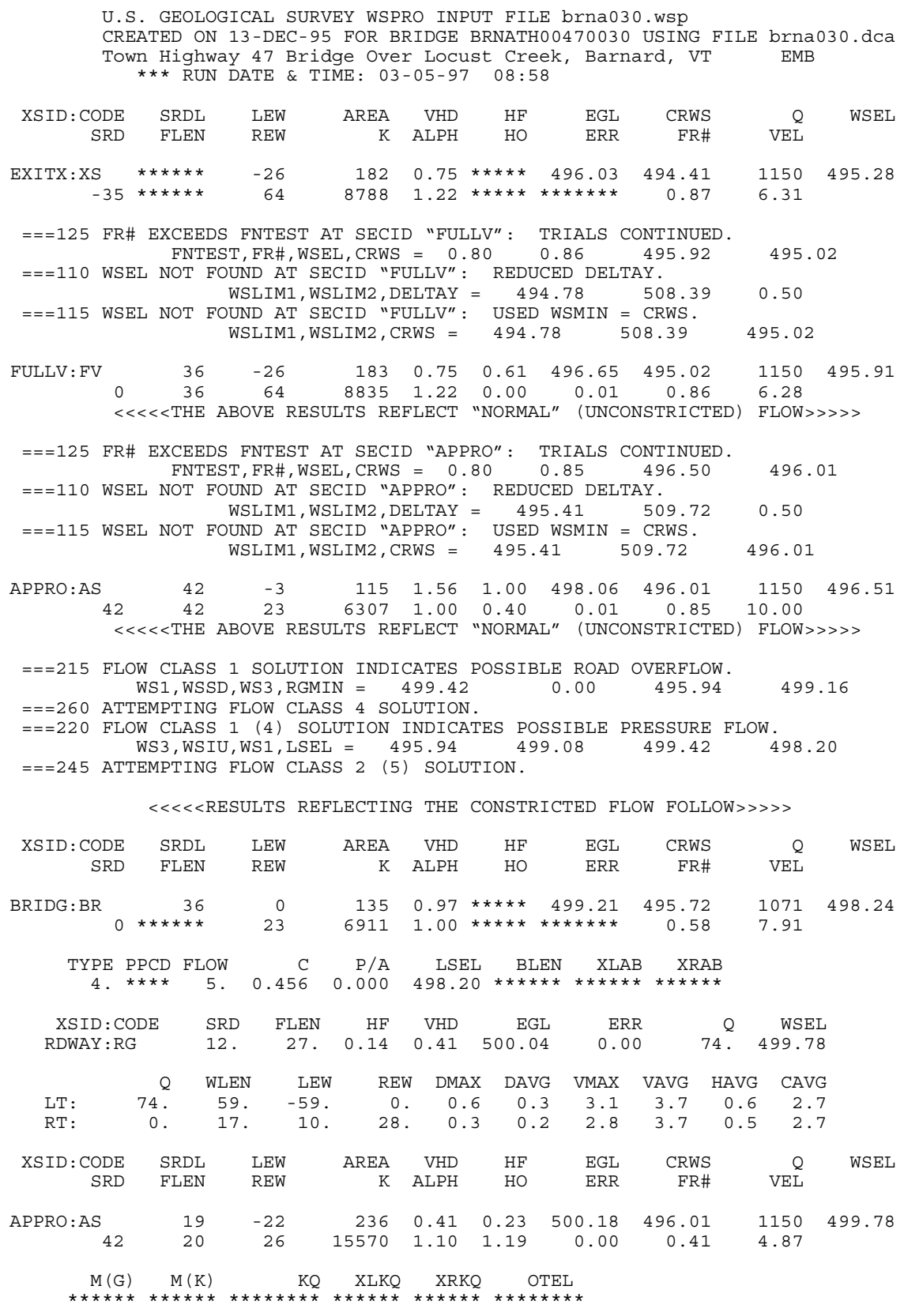

$\ll<<<$ END OF BRIDGE COMPUTATIONS $>>>>>$

FIRST USER DEFINED TABLE.

$\begin{array}{lrrrrrrrr}\text { XSID : CODE } & \text { SRD } & \text { LEW } & \text { REW } & Q & \text { K } & \text { AREA } & \text { VEL } & \text { WSEL } \\ \text { EXITX : XS } & -36 . & -27 . & 64 . & 1150 . & 8788 . & 182 . & 6.31 & 495.28 \\ \text { FULLV : FV } & 0 . & -27 . & 64 . & 1150 . & 8835 . & 183 . & 6.28 & 495.91 \\ \text { BRIDG }: \text { BR } & 0 . & 0 . & 23 . & 1071 . & 6911 . & 135 . & 7.91 & 498.24 \\ \text { RDWAY : RG } & 12 . * * * * * * * & 74 . & 74 . & 0 . & 0 . & 2.00 & 499.78 \\ \text { APPRO : AS } & 42 . & -23 . & 26 . & 1150 . & 15570 . & 236 . & 4.87 & 499.78\end{array}$

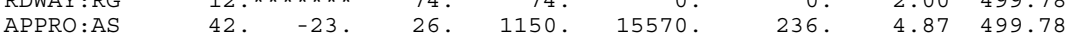

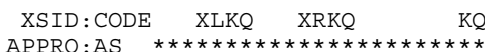

SECOND USER DEFINED TABLE.

$\begin{array}{lcrrrrrrrr}\text { XSID :CODE } & \text { CRWS } & \text { FR\# } & \text { YMIN } & \text { YMAX } & \text { HF } & \text { HO } & \text { VHD } & \text { EGL } & \text { WSEL } \\ \text { EXITX:XS } & 494.41 & 0.87 & 489.73 & 507.77 * * * * * * * * * * * & 0.75 & 496.03 & 495.28 \\ \text { FULLV:FV } & 495.02 & 0.86 & 490.35 & 508.39 & 0.61 & 0.00 & 0.75 & 496.65 & 495.91 \\ \text { BRIDG :BR } & 495.72 & 0.58 & 489.97 & 498.24 * * * * * * * * * & 0.97 & 499.21 & 498.24 \\ \text { RDWAY:RG } & * * * * * * * * * * * * * * & 499.16 & 508.07 & 0.14 * * * * * & 0.41 & 500.04 & 499.78 \\ \text { APPRO :AS } & 496.01 & 0.41 & 490.66 & 509.72 & 0.23 & 1.19 & 0.41 & 500.18 & 499.78\end{array}$


WSPRO OUTPUT FILE (continued)

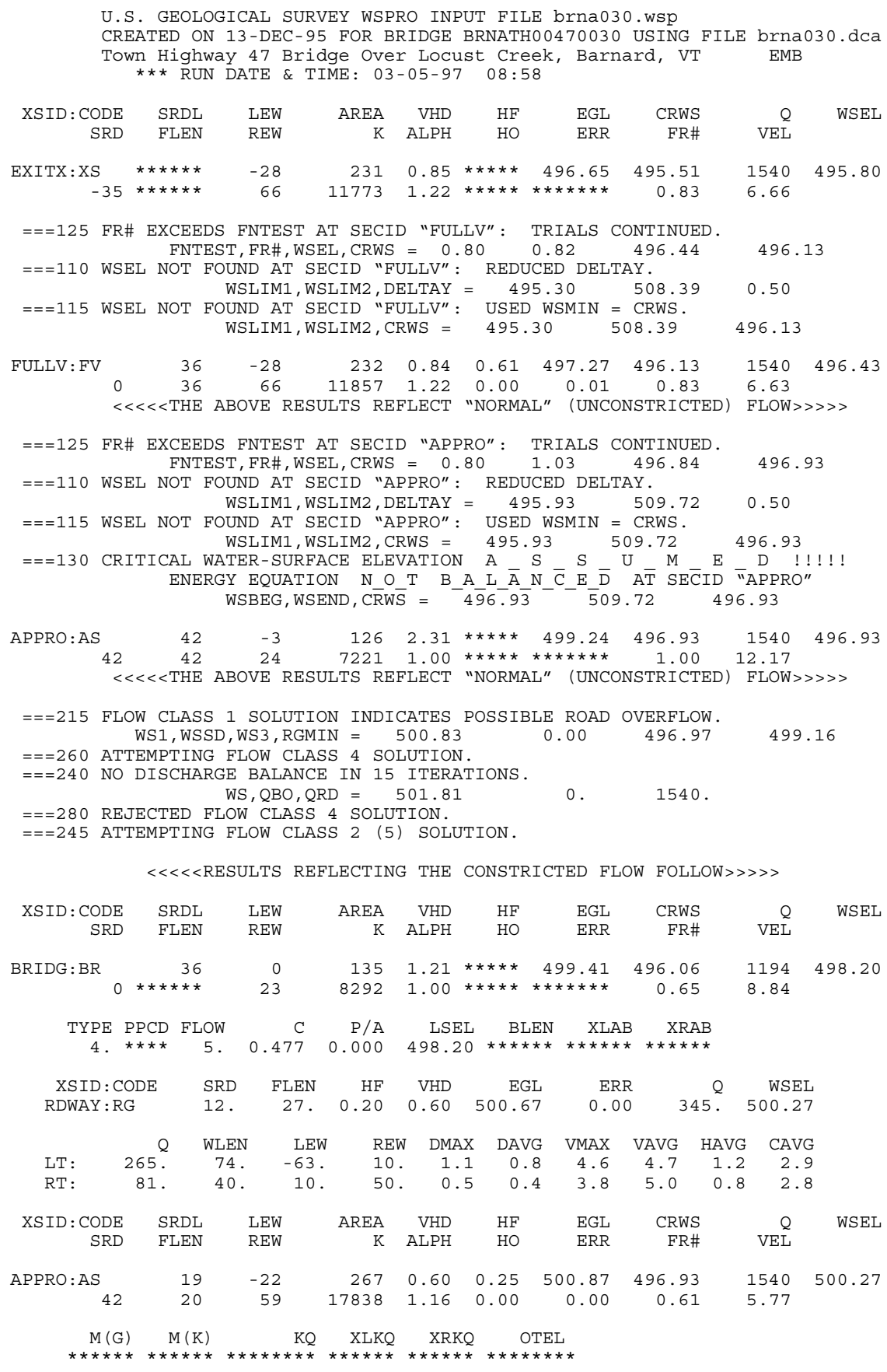

$<<<<$ END OF BRIDGE COMPUTATIONS $>>>>>$

FIRST USER DEFINED TABLE.

\begin{tabular}{|c|c|c|c|c|c|c|c|c|}
\hline XSID : CODE & SRD & LEW & REW & 0 & $\mathrm{~K}$ & AREA & VEL & WSEL \\
\hline EXITX:XS & -36. & -29 & 66. & 1540. & 11773. & 231. & 6.66 & 495.80 \\
\hline FULLV : FV & 0. & -29 & 66. & 1540. & 11857. & 232 . & 6.63 & 496.43 \\
\hline BRIDG : BR & 0 . & 0 . & 23. & 1194. & 8292. & 135. & 8.84 & 498.20 \\
\hline RDWAY : RG & 12. & $\star \star \star \star \star *$ & 265. & 345 . & 0 . & 0 . & 2.00 & 500.27 \\
\hline APPRO : AS & 42. & -23 & 59. & 1540. & 17838 & 267 . & 5.77 & 500.27 \\
\hline XSID : CODE & LKQ & XRKQ & & & & & & \\
\hline
\end{tabular}

SECOND USER DEFINED TABLE.

\begin{tabular}{|c|c|c|c|c|c|c|c|c|c|}
\hline XSID : CODE & CRWS & FR\# & YMIN & YMAX & $\mathrm{HF}$ & $\mathrm{HO}$ & VHD & EGL & \\
\hline EXITX & 495.51 & .83 & 489.73 & 507.77 * & $\star * \star \star \star * \star *$ & $\star * \star * *$ & 0.85 & 496.65 & \\
\hline FULLV : FV & & & 90.35 & 508.39 & 0.61 & 0.00 & & & \\
\hline $\mathrm{R}$ & 5.06 & 65 & 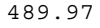 & 498.24 * & $\star \star \star \star \star \star *$ & $\approx *$ & & & \\
\hline G & $\star$ & $\star \star \star \star *$ & 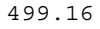 & 508.07 & $0.20 * x$ & $\star \star \star \star * \star *$ & 0 & 67 & \\
\hline PPRO & 496.93 & 0.61 & 490.66 & 509.72 & 0.25 & 0.00 & 0.60 & 500.87 & 0 \\
\hline
\end{tabular}


WSPRO OUTPUT FILE (continued)

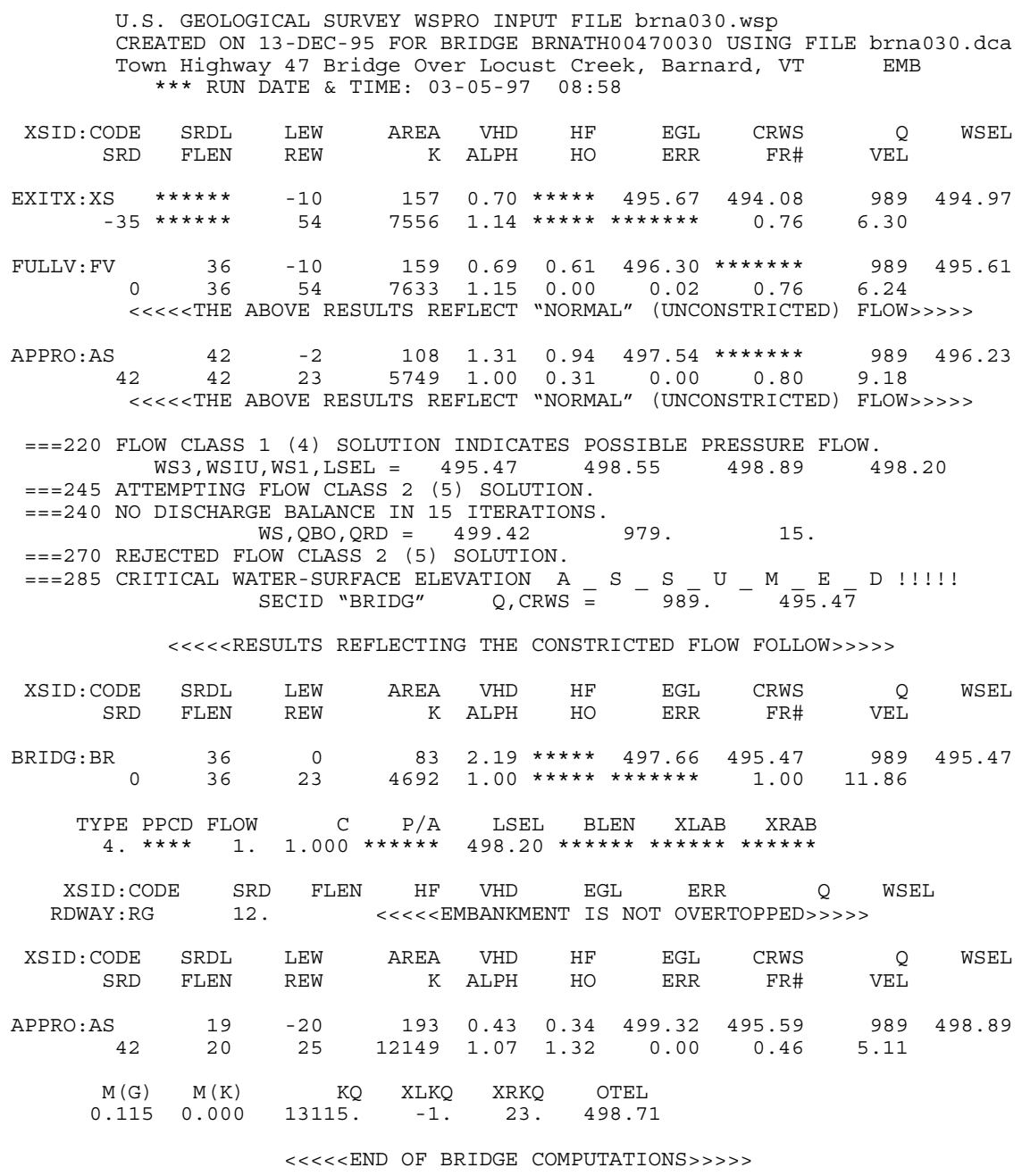

FIRST USER DEFINED TABLE.

\begin{tabular}{|c|c|c|c|c|c|c|c|c|}
\hline XSID : CODE & SRD & LEW & REW & Q & K & AREA & VEL & WSEL \\
\hline EXITX:XS & -36. & -11 & 54. & 989. & 7556. & 157. & 6.30 & 494.97 \\
\hline FULLV : FV & 0 . & -11 & 54. & 989. & 7633. & 159. & 6.24 & 495.61 \\
\hline BRIDG : BR & 0 . & 0 . & 23. & 989. & 4692 . & 83. & 11.86 & 495.47 \\
\hline RDWAY : RG & 12. & $\star \star \star \star \star \star *$ & $\star \star \star * *$ & 0 . & 0 . & 0 . & 2.00 & 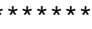 \\
\hline APPRO: AS & 42 . & -21 & 25 . & 989. & 12149. & 193. & 5.11 & 498.89 \\
\hline XSID : CODE & XLKQ & XRKQ & & & & & & \\
\hline APPRO:AS & -1 & 23 . & 1311 & & & & & \\
\hline
\end{tabular}

SECOND USER DEFINED TABLE.

\begin{tabular}{|c|c|c|c|c|c|c|c|c|c|}
\hline XSID: CODE & CRWS & FR\# & YMIN & YMAX & $\mathrm{HF}$ & $\mathrm{HO}$ & VHD & EGL & WSEL \\
\hline EXITX:XS & 494.08 & 0.76 & 489.73 & 507.77 * & $\star \star \star \star \star \star *$ & 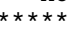 & 0.70 & 495.67 & 494.97 \\
\hline FULLV : FV & 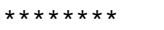 & 0.76 & 490.35 & 508.39 & 0.61 & 0.00 & 0.69 & 496.30 & 495.61 \\
\hline BRIDG : BR & 495.47 & 1.00 & 489.97 & 498.24 * & 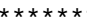 & $\star \star \star \star \star *$ & 2.19 & 497.66 & 495.47 \\
\hline RDWAY : RG & 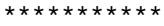 & $\star \star \star \star * *$ & 499.16 & $508.07 *$ & $\star \star \star \star \star \star \star *$ & 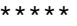 & 0.35 & 499.64 * & $\star \star \star \star \star \star * \star *$ \\
\hline APPRO:AS & 495.59 & 0.46 & 490.66 & 509.72 & 0.34 & 1.32 & 0.43 & 499.32 & 498.89 \\
\hline
\end{tabular}




\section{APPENDIX C:}

\section{BED-MATERIAL PARTICAL-SIZE DISTRIBUTION}




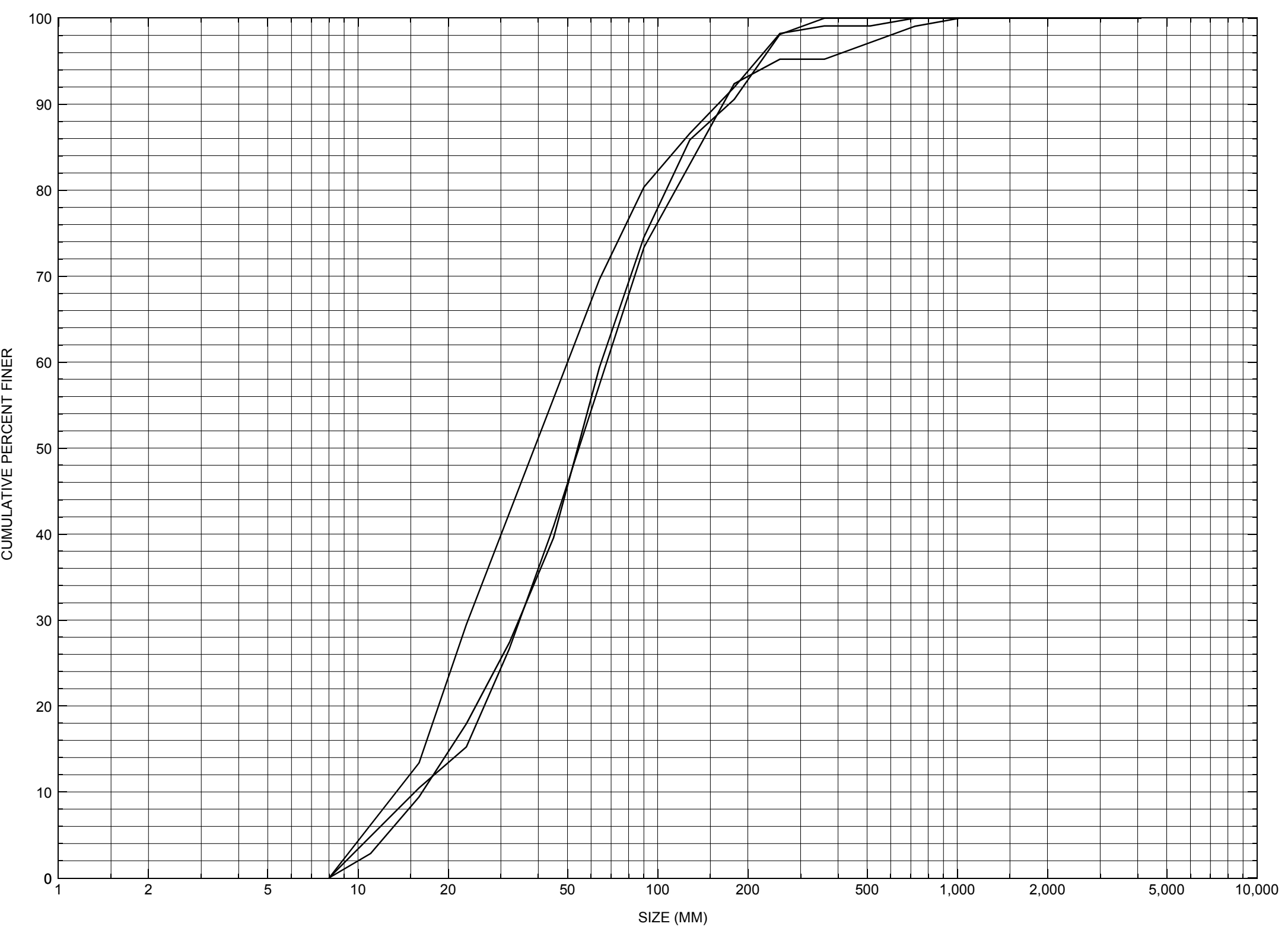

Appendix C. Bed material particle-size distribution for three pebble count transects in the channel approach of structure BRNATH00470030, in Barnard, Vermont. 


\section{APPENDIX D: \\ HISTORICAL DATA FORM}




\section{Structure Number BRNATH00470030}

\section{General Location Descriptive}

Data collected by (First Initial, Full last name) M. IVANOFF

Date $(M M / D D / Y Y) \_\mathbf{0 8} / \underline{\mathbf{2 3}} / \underline{\mathbf{9 4}}$

Highway District Number (I - 2; nn) 04

Town (FIPS place code; I - 4; nnnnn) $\mathbf{0 2 7 2 5}$

Waterway (I - 6) Locust Creek

Route Number $\underline{\text { TH } 47}$

Topographic Map Delectable.Mtn

Latitude (I - 16; nnnn.n) $\mathbf{4 3 4 2 6}$
County (FIPS county code; I - 3; nnn)

Mile marker (I - 11; nnn.nnn) $\mathbf{0 0 0 0 0 0}$

Road Name (I - 7): -

Vicinity (I - 9) 0.05 MI TO JCT W C3 TH48

Hydrologic Unit Code: $\mathbf{0 1 0 8 0 1 0 5}$

Longitude (i - 17; nnnnn.n) $\mathbf{7 2 3 8 8}$

\section{Select Federal Inventory Codes}

FHWA Structure Number (I - 8) 10140300301403

Maintenance responsibility $(I-21 ; n n) \quad \mathbf{0 3} \quad$ Maximum span length $(I-48 ; n n n n) \underline{\mathbf{0 0 2 5}}$

Year built (I - 27; YYYY) 1977

Structure length (I - 49; nnnnnn) $\underline{\mathbf{0 0 0 0 2 8}}$

Average daily traffic, ADT (I - 29; nnnnnn) 000010 Deck Width (I - 52; nn.n) 155

Year of ADT (I - 30; YY) $\mathbf{9 0}$

Channel \& Protection $(I-61 ; n) \underline{\mathbf{8}}$

Opening skew to Roadway $(I-34 ; n n) \quad \mathbf{4 5}$

Waterway adequacy $(I-71 ; n) \underline{7}$

Operational status $(I-41 ; X)$ A

Underwater Inspection Frequency $(I-92 B ; X Y Y) \_\mathbf{N}$

Structure type (I - 43; nnn) 101

Year Reconstructed (I - 106) $\mathbf{0 0 0 0}$

Approach span structure type (I - 44; nnn) $\mathbf{0 0 0}$

Clear span (nnn.n ft)

Number of spans (I - 45; nnn) $\mathbf{0 0 1}$

Vertical clearance from streambed (nnn.n ft) $\underline{\mathbf{0 0 6 . 5}}$

Number of approach spans $(I-46 ; n n n n) \underline{\mathbf{0 0 0 0}}$ Waterway of full opening $\left(n n n . n f^{2}\right) \underline{\mathbf{1 0 5 . 0}}$

Comments:

Structural inspection report of 5/23/94 indicates the abutment footings are not in view [at the surface] and no settlement is apparent. Status of embankment erosion and channel scour are not addressed in the report. Report noted a straight stream alignment through bridge crossing. Riprap and drift/vegetation are not addressed in the report. 


\section{Bridge Hydrologic Data}

Is there hydrologic data available? $\underline{\mathbf{Y}}$ if No, type ctrl- $n$ VTAOT Drainage area $\left(\mathrm{mi}^{2}\right): \underline{\mathbf{5 . 2}}$

Terrain character:

Stream character \& type: -

Streambed material:

Discharge Data (cfs):

$$
\mathrm{Q}_{2.33} \frac{-}{\mathbf{9 5 0}}
$$

$\mathrm{Q}_{10} \frac{\mathbf{5 0 0}}{\mathbf{1 1 5 0}}$

$\mathrm{Q}_{25} \mathbf{7 5 0}$

$Q_{500}$

Record flood date (MM/DD/YY): - $/$ - $/$ -

Water surface elevation $(f t):-$

Estimated Discharge (cfs): _ _ Velocity at Q 25 (ft/s): $\underline{\mathbf{1 1 . 4 7}}$

Ice conditions (Heavy, Moderate, Light) : -

Debris (Heavy, Moderate, Light):

The stage increases to maximum highwater elevation (Rapidly, Not rapidly):

The stream response is (Flashy, Not flashy):

Describe any significant site conditions upstream or downstream that may influence the stream's stage: -

Watershed storage area (in percent):

The watershed storage area is: - _ (1-mainly at the headwaters; 2- uniformly distributed; 3-immediatly upstream oi the site)

Water Surface Elevation Estimates for Existing Structure:

\begin{tabular}{|l|l|l|l|l|l|}
\hline Peak discharge frequency & $Q_{2.33}$ & $Q_{10}$ & $Q_{25}$ & $Q_{50}$ & $Q_{100}$ \\
Water surface elevation (ft) $)$ & - & $\mathbf{4 . 3}$ & $\mathbf{5 . 6}$ & $\mathbf{6 . 8}$ & $\mathbf{7 . 6}$ \\
Velocity $(\mathrm{ft} / \mathrm{sec})$ & - & - & $\mathbf{1 1 . 4 7}$ & - & - \\
\hline
\end{tabular}

Long term stream bed changes: -

Is the roadway overtopped below the $\mathrm{Q}_{100}$ ? (Yes, No, Unknown): $\mathbf{U}$ Frequency: -

Relief Elevation $(f t)$ :

Discharge over roadway at $Q_{100}\left(f^{3} / \mathrm{sec}\right)$ :

Are there other structures nearby? (Yes, No, Unknown): $\mathbf{U}$ Upstream distance (miles): Town: If No or Unknown, type ctrl-n os Highway No. : Structure No. : Year Built:

Clear span (ft): Clear Height (ft): Full Waterway $\left(f^{2}\right)$ : 
Downstream distance (miles): Town: Year Built:

Highway No. : Structure No. : Structure Type:

Clear span (ft): Clear Height $(f t)$ : Full Waterway $\left(f t^{2}\right)$ :

Comments:

\section{USGS Watershed Data}

Watershed Hydrographic Data

Drainage area (DA)

4.18 $\mathrm{mi}^{2}$

Watershed storage (ST) 0

Bridge site elevation 1370

Main channel length 3.59 $\mathrm{ft}$ $\%$

Lake and pond area

$\mathbf{0}$ $\mathrm{mi}^{2}$ $10 \%$ channel length elevation mi

Headwater elevation 2836 $\mathrm{ft}$

Main channel slope (S)
(S) 259.99 $\mathrm{ft} / \mathrm{mi}$

Watershed Precipitation Data

Average site precipitation in

Average headwater precipitation in

Maximum 2yr-24hr precipitation event $(124,2)$ in

Average seasonal snowfall (Sn) $\mathrm{ft}$ 


\section{Bridge Plan Data}

Are plans available? $\underline{Y}$ If no, type ctrl-n pl Date issued for construction (MM/YYYY): 04 / 1977 Project Number DSR 0024

Minimum channel bed elevation: 495.5

Low superstructure elevation: USLAB $\underline{\mathbf{5 0 0 . 3 1}}$ DSLAB $\mathbf{5 0 0 . 2 9}$ USRAB $\mathbf{5 0 0 . 3 6}$ DSRAB $\underline{\mathbf{5 0 0 . 3 4}}$

Benchmark location description:

BM\#1, S.I.T. (spike in tree); 8 inch yellow birch at upstream edge of old roadway leading to the water at the downstream right abutment, stationing $13+17,23$ feet right, elevation 500.00. BM\#2, S.I.T.; 30 inch pine at downstream side of old roadway leading to the water at the downstream left abutment, stationing $15+00,24$ feet right, elevation 501.40.

Reference Point (MSL, Arbitrary, Other): Arbitrary $\quad$ Datum (NAD27, NAD83, Other): Arbitrary Foundation Type: 1 (1-Spreadfooting; 2-Pile; 3- Gravity; 4-Unknown)

If 1: Footing Thickness $\underline{\mathbf{2 . 0}}$ Footing bottom elevation: $\underline{\mathbf{4 9 1 . 0}}$

If 2: Pile Type: ___ (1-Wood; 2-Steel or metal; 3-Concrete) Approximate pile driven length: -

If 3: Footing bottom elevation: -

Is boring information available? $\mathbf{N}$ If no, type ctrl-n bi Number of borings taken: -

Foundation Material Type: $\mathbf{3}$ (1-regolith, 2-bedrock, 3-unknown)

Briefly describe material at foundation bottom elevation or around piles:

NO FOUNDATION MATERIAL INFORMATION

Comments:

Some hydraulic data is also included on plans: $Q 10=500$, height 4.3 feet, $Q 25=750$, height 5.6 feet, $Q 50=950$, height 6.8 feet, $Q 100=1150$, height 7.6 feet, outlet velocity at $Q 25=11.47$ feet per second, drainage area $=4.2$ square miles. 


\section{Cross-sectional Data}

Is cross-sectional data available? $\underline{\mathbf{Y}}$ If no, type ctrl-n xs

Source (FEMA, VTAOT, Other)? VTAOT

Comments: There are several cross sections that are printed and kept with the plans, and may be retrieved if needed. There are no reproducible bridge face cross sections.

\begin{tabular}{|l|l|l|l|l|l|l|l|l|l|l|l|}
\hline Station & & & & & & & & & & & \\
\hline Feature & & & & & & & & & & & \\
\hline $\begin{array}{l}\text { Low cord } \\
\text { elevation }\end{array}$ & & & & & & & & & & & \\
\hline $\begin{array}{l}\text { Bed } \\
\text { elevation }\end{array}$ & & & & & & & & & & & \\
\hline $\begin{array}{l}\text { Low cord to } \\
\text { bed length }\end{array}$ & & & & & & & & & & & \\
\hline Station & & & & & & & & & & & \\
\hline Feature & & & & & & & & & & & \\
\hline $\begin{array}{l}\text { Low cord } \\
\text { elevation }\end{array}$ & & & & & & & & & & & \\
\hline $\begin{array}{l}\text { Bed } \\
\text { elevation }\end{array}$ & & & & & & & & & & & \\
\hline $\begin{array}{l}\text { Low cord to } \\
\text { bed length }\end{array}$ & & & & & & & & & & & \\
\hline
\end{tabular}

Source (FEMA, VTAOT, Other)?

Comments:

\begin{tabular}{|l|l|l|l|l|l|l|l|l|l|l|l|}
\hline Station & & & & & & & & & & & \\
\hline Feature & & & & & & & & & & & \\
\hline $\begin{array}{l}\text { Low cord } \\
\text { elevation }\end{array}$ & & & & & & & & & & & \\
\hline $\begin{array}{l}\text { Bed } \\
\text { elevation }\end{array}$ & & & & & & & & & & & \\
\hline $\begin{array}{l}\text { Low cord to } \\
\text { bed length }\end{array}$ & & & & & & & & & & & \\
\hline Station & & & & & & & & & & & \\
\hline Feature & & & & & & & & & & & \\
\hline $\begin{array}{l}\text { Low cord } \\
\text { elevation }\end{array}$ & & & & & & & & & & & \\
\hline $\begin{array}{l}\text { Bed } \\
\text { elevation }\end{array}$ & & & & & & & & & & & \\
\hline $\begin{array}{l}\text { Low cord to } \\
\text { bed length }\end{array}$ & & & & & & & & & & & \\
\hline
\end{tabular}




\section{APPENDIX E: \\ LEVEL I DATA FORM}


U. S. Geological Survey

Bridge Field Data Collection and Processing Form

Qa/Qc Check by: EMB Date: $1 / 26 / 95$

\section{Structure Number}

BRNATH00470030

Computerized by: EMB Date: $\underline{\mathbf{1} / \mathbf{2 6} / \mathbf{9 5}}$

Reviewd by: JDA Date: 11/4/95

\section{A. General Location Descriptive}

1. Data collected by (First Initial, Full last name) D. SONG

Date $(M M / D D / Y Y) \underline{10} / \underline{13} / \underline{1994}$

2. Highway District Number $\mathbf{0 4}$

County Windsor (027)

Mile marker -

Waterway (I - 6) Locust Creek

Route Number TH47

Town Barnard (02725)

Road Name -

Hydrologic Unit Code: $\mathbf{0 1 0 8 0 1 0 5}$

3. Descriptive comments:

Small, remote bridge on cobble bed stream located about 250 feet (0.05 miles) from town highway 47 's intersection with town highway 48.

\section{B. Bridge Deck Observations}
4. Surface cover... LBUS 6
RBUS 6
LBDS 5
RBDS 5
Overall 6

(2b us, ds,lb,rb: 1- Urban; 2- Suburban; 3- Row crops; 4- Pasture; 5- Shrub- and brushland; 6- Forest; 7- Wetland)
5. Ambient water surface... US $\underline{2}$
UB 1 DS 2
(1- pool; 2- riffle)

6. Bridge structure type 1 (1- single span; 2- multiple span; 3- single arch; 4- multiple arch; 5-cylindrical culvert; 6- box culvert; or 7- other)
7. Bridge length 28.0
(feet)
Span length $\mathbf{2 5 . 0}$
(feet)
Bridge width 15.5 (feet)

\section{Road approach to bridge:}
8. LB 0
RB 0
( 0 even, 1- lower, 2- higher)
9. LB_2
RB $\underline{2}$
(1- Paved, 2- Not paved)

10. Embankment slope (run / rise in feet / foot)

$$
\text { US left }
$$

8.1:1

US right

4.1:1

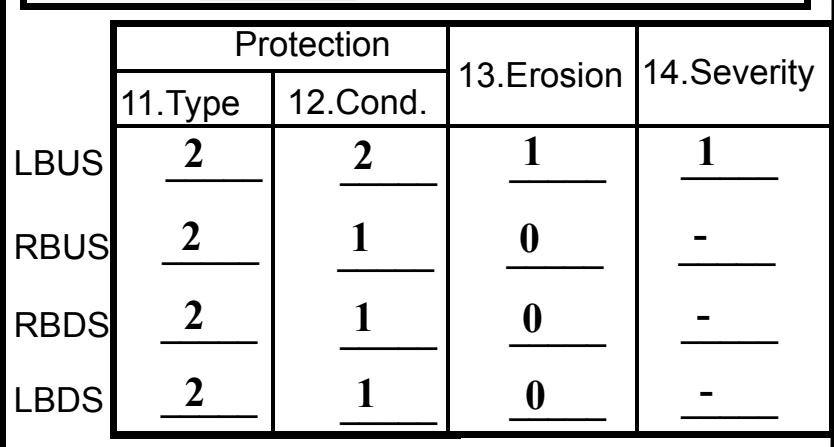

Bank protection types: 0- none; 1- $<12$ inches;

2- < 36 inches; 3- < 48 inches;

4- < 60 inches; 5- wall / artificial levee

Bank protection conditions: 1- good; 2- slumped;

3- eroded; 4- failed

Erosion: 0 - none; 1- channel erosion; 2 -

road wash; 3- both; 4- other

Erosion Severity: 0 - none; 1- slight; 2- moderate; 3- severe

\section{Channel approach to bridge (BF):}

15. Angle of approach: 15

16. Bridge skew: $\mathbf{4 0}$

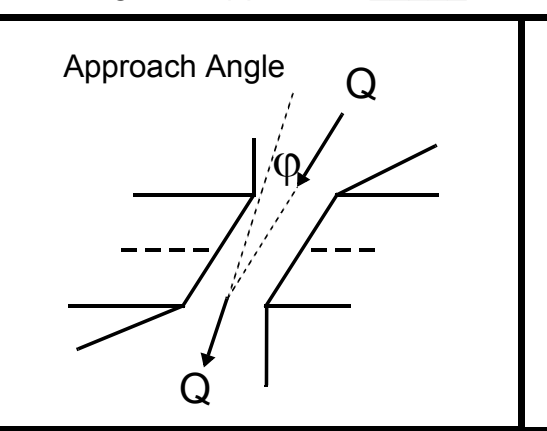

17. Channel impact zone 1:

Where? LB $(L B, R B)$

Range? 10 feet US

Channel impact zone 2:

Where? $(L B, R B)$

Range? - $\quad$ feet -

(US, UB, DS) to feet Impact Severity: 0- none to very slight; 1- Slight; 2- Moderate; 3- Severe

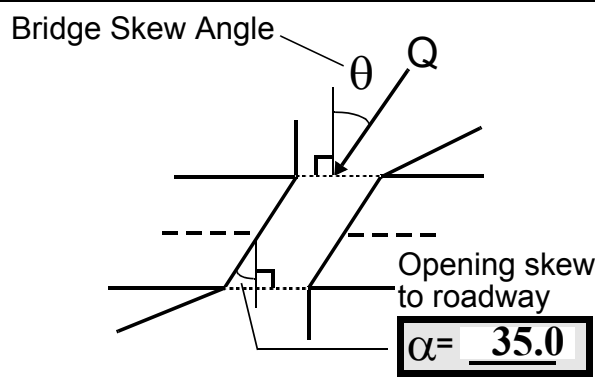

Exist? $\mathbf{Y}(Y$ or $N)$

Severity 1

US, UB, DS) to $\underline{\mathbf{0}}$ feet $\underline{\mathbf{D S}}$

Exist? $\mathbf{N}(Y$ or $N)$

Severity - 
18. Bridge Type: 4

1a- Vertical abutments with wingwalls

$1 \mathrm{~b}$ - Vertical abutments without wingwalls

2- Vertical abutments and wingwalls, sloping embankment

Wingwalls perpendicular to abut. face

3- Spill through abutments

4- Sloping embankment, vertical wingwalls and abutments

Wingwall angle less than $90^{\circ}$.

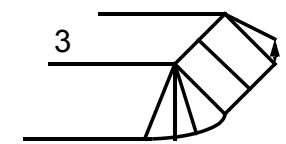

19. Bridge Deck Comments (surface cover variations, measured bridge and span lengths, bridge type variations, approach overflow width, etc.)

Predominantly young trees, brush with forest land beyond 1 bridge length on left and right bank downstream. Measured bridge dimensions are: Bridge length $=28.0$; Span length $=24.0$; and roadway width $=15.0$ feet.

\section{Upstream Channel Assessment}

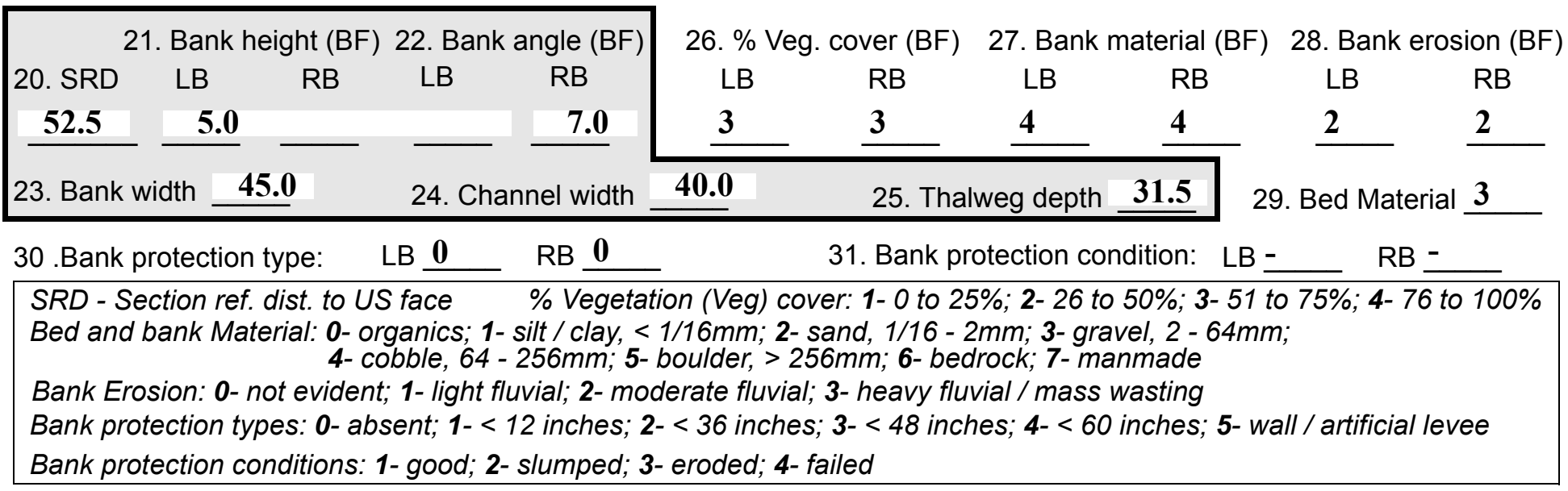

32. Comments (bank material variation, minor inflows, protection extent, etc.):

Bank material is mainly organics and sand overlying cobbles with interstitial fines. While banks are undermined, they appear stabilized by trees. The streambed material is predominantly coarse gravel with some cobbles and a few boulders. 
33.Point/Side bar present? $\mathbf{N}(Y$ or $N$. if $N$ type ctrl-n pb)34. Mid-bar distance: -

35. Mid-bar width: -

36. Point bar extent: feet (US, UB) to feet (US, UB, DS) positioned $\%$ LB to $\% \mathrm{RB}$

37. Material: -

38. Point or side bar comments (Circle Point or Side; Note additional bars, material variation, status, etc.):

NO POINT BARS

39. Is a cut-bank present? $\mathbf{Y}$ (Y or if $N$ type ctrl-n cb) 40. Where? $\underline{\mathbf{L B}}$ (LB or $R B)$

41. Mid-bank distance: $\mathbf{4 0 . 0}$

42. Cut bank extent: $\underline{\mathbf{7 5 . 0}}$ feet $\mathrm{US}$ (US, UB) to $\mathbf{1 0}$ feet $\underline{\mathbf{U S}}$ (US, UB, DS)

43. Bank damage: 1 (1- eroded and/or creep; 2- slip failure; 3- block failure)

44. Cut bank comments (eg. additional cut banks, protection condition, etc.):

Severe undermining stabilized by trees (the cutbank ends around the upstream left wingwall due to boulder protection). Another cutbank is present on right bank just upstream of the upstream end of the above defined cutbank. Bank is steep and slumped (mass wasting) which appears due to the entrance of a confluence on left bank. The cut bank extent is from 70 feet upstream to 120 feet upstream on the right bank.

45. Is channel scour present? $\mathbf{N}$ (Yor if $N$ type ctrl-n cs) 46. Mid-scour distance: -

47. Scour dimensions: Length Width Depth : -

Position $\%$ LB to $\% \mathrm{RB}$

48. Scour comments (eg. additional scour areas, local scouring process, etc.):

NO CHANNEL SCOUR

49. Are there major confluences? $\mathbf{Y}$ (Y or if $N$ type ctrl-n $m c)$

51. Confluence 1: Distance 130 Confluence 2: Distance 52. Enters on $\underline{\mathbf{L B}}$ (LB or RB) Enters on (LB or $R B)$

54. Confluence comments (eg. confluence name):

The confluence is about 10 feet wide with an ambient flow depth of less than 0.5 feet. However, it will deliver a good percentage of flow and has influenced bank degradation on right bank just downstream of its

\section{Under Bridge Channel Assessment}

55. Channel restraint (BF)? LB entr (1- natural bank; 2- abutment; 3- artificial levee)

\begin{tabular}{|c|c|c|c|c|c|c|c|}
\hline \multicolumn{2}{|c|}{ 56. Height (BF) } & \multicolumn{2}{|c|}{57 Angle (BF) } & \multicolumn{2}{|c|}{ 61. Material (BF) } & \multicolumn{2}{|c|}{ 62. Erosion $(\mathrm{BF})$} \\
\hline LB & RB & LB & RB & LB & RB & LB & $\mathrm{RB}$ \\
\hline & & & & ance. & 2 & 2 & 7 \\
\hline
\end{tabular}

58. Bank width (BF) 59. Channel width $(\mathrm{Amb})$ 60. Thalweg depth (Amb) $\mathbf{9 0 . 0}$ 63. Bed Material 7

Bed and bank Material: 0- organics; 1- silt / clay, < 1/16mm; 2- sand, 1/16 - 2mm; 3- gravel, 2 - 64mm; 4- cobble, 64 - 256mm; 5- boulder, > 256mm; 6- bedrock; 7- manmade

Bank Erosion: 0- not evident; 1- light fluvial; 2- moderate fluvial; 3- heavy fluvial / mass wasting

64. Comments (bank material variation, minor inflows, protection extent, etc.):

$-$

3 
65. Debris and Ice Is there debris accumulation?

(Yor $N)$ 66. Where?

(1- Upstream; 2- At bridge; 3- Both)

67. Debris Potential (1- Low; 2- Moderate; 3- High)

68. Capture Efficiency $\mathbf{N}$ (1-Low; 2- Moderate; 3- High)

69. Is there evidence of ice build-up? - $(Y$ or $N)$

Ice Blockage Potential $\underline{2}$ (1-Low; 2- Moderate; 3- High)

70. Debris and Ice Comments:

2

$\mathbf{N}$

2

Relatively small bridge opening with alot of deadwood. A point bar under the bridge constricts the opening, raising the potential for blockage at this site.

\begin{tabular}{|l|c|c|c|c|c|c|c|c|}
\hline Abutments & $\begin{array}{c}\text { 71. Attack } \\
\angle \mathrm{BF})\end{array}$ & $\begin{array}{c}\text { 72. Slope } \\
(\mathrm{Qmax})\end{array}$ & $\begin{array}{l}\text { 73. Toe } \\
\text { loc. (BF) }\end{array}$ & $\begin{array}{c}\text { 74. Scour } \\
\text { Condition }\end{array}$ & $\begin{array}{c}\text { 75. Scour } \\
\text { depth }\end{array}$ & $\begin{array}{c}\text { 76. Exposure } \\
\text { depth }\end{array}$ & 77. Material & 78. Length \\
\hline LABUT & & & & $\mathbf{1 0}$ & $\mathbf{9 0}$ & $\mathbf{2}$ & $\mathbf{1}$ & $\mathbf{9 0 . 0}$ \\
\hline RABUT & $\mathbf{0 . 5}$ & & $\mathbf{1}$ & & & - & $\mathbf{9 0}$ & $\mathbf{1 9 . 0}$ \\
\hline
\end{tabular}

Pushed: $L B$ or RB

Toe Location (Loc.): 0- even, 1- set back, 2- protrudes

Scour cond.: 0- not evident; 1- evident (comment); 2- footing exposed; 3-undermined footing; 4- piling exposed; 5- settled; 6- failed

Materials: 1- Concrete; 2- Stone masonry or drywall; 3- steel or metal; 4- wood

79. Abutment comments (eg. undermined penetration, unusual scour processes, debris, etc.):

2

0

1

The streambed elevation along the left abutment is lower than on the right abutment where the flow impacts the left abutment and scour has occurred.

80. Wingwalls:

Exist? Material? Scour Scour Exposure Angle? Length? Condition? depth? depth?

USLWW:

USRWW:

DSLWW: 1

DSRWW:

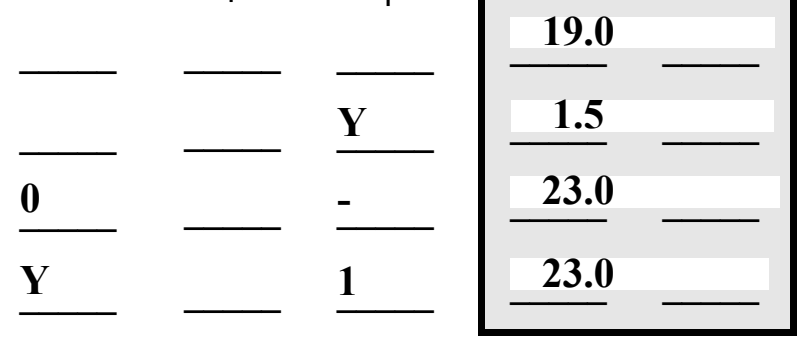

Wingwall materials: 1- Concrete; 2- Stone masonry or drywall; 3- steel or metal; 4- wood

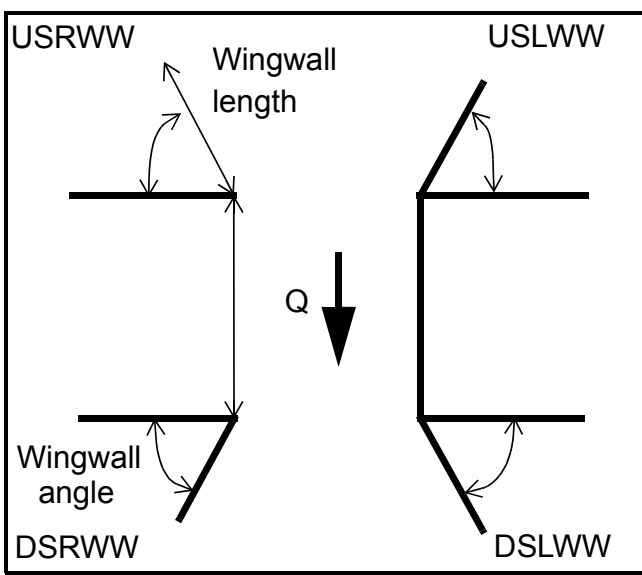

82. Bank / Bridge Protection:

\begin{tabular}{|l|l|l|l|l|l|l|l|l|}
\hline Location & USLWW & USRWW & LABUT & RABUT & LB & RB & DSLWW & DSRWW \\
\hline Type & $\mathbf{0}$ & $\mathbf{Y}$ & - & $\mathbf{1}$ & & $\mathbf{1}$ & $\mathbf{1}$ & - \\
\hline Condition & - & $\mathbf{1}$ & & $\mathbf{0}$ & $\mathbf{2}$ & $\mathbf{2}$ & $\mathbf{0}$ & $\mathbf{0}$ \\
\hline Extent & & $\mathbf{0}$ & $\mathbf{Y}$ & - & $\mathbf{2}$ & $\mathbf{1}$ & - & - \\
\hline
\end{tabular}

Bank / Bridge protection types: 0- absent; 1-<12 inches; 2- < 36 inches; 3- < 48 inches; 4- < 60 inches; 5- wall / artificial levee

Bank / Bridge protection conditions: 1- good; 2- slumped; 3- eroded; 4- failed

Protection extent: 1- entire base length; 2- US end; 3- DS end; 4- other 
83. Wingwall and protection comments (eg. undermined penetration, unusual scour processes, etc.):

-
-
-
-
-
-
-
2
1
3
3

\section{Piers:}

84. Are there piers? 1 (Y or if $N$ type ctrl-n pr)

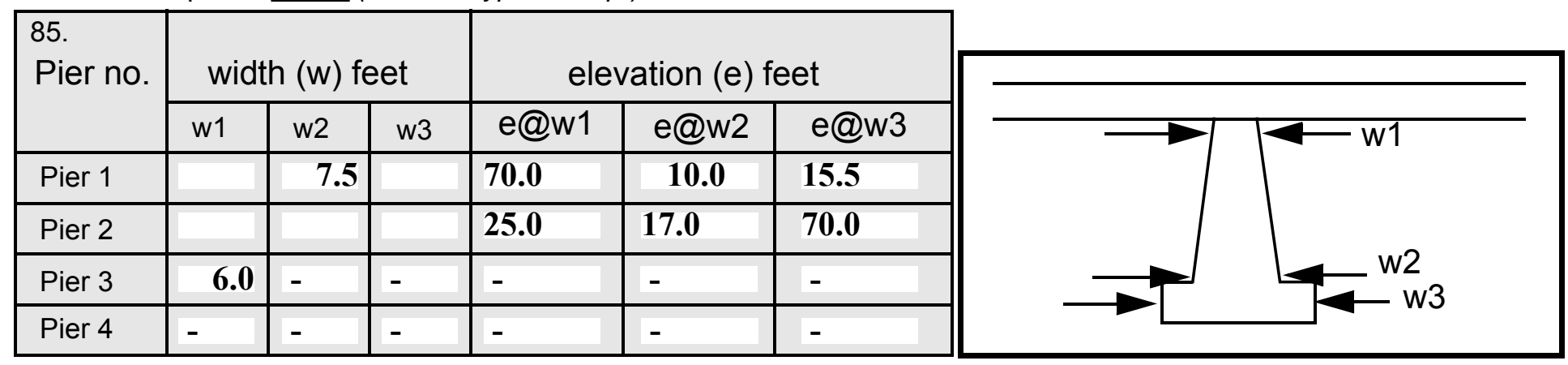

\begin{tabular}{|l|l|l|l|l|}
\hline Level 1 Pier Descr. & \multicolumn{1}{|c|}{1} & \multicolumn{1}{|c|}{2} & 3 & \multicolumn{1}{|c|}{} \\
\hline 86. Location (BF) & 1 & tered & & - \\
\hline 87. Type & Rem & alon & & - \\
\hline 88. Material & nant & g & & - \\
\hline 89. Shape & s of & both & & - \\
\hline 90. Inclined? & the & abut & & - \\
\hline 91. Attack $\angle$ (BF) & wing & ment & N & - \\
\hline 92. Pushed & wall & s. & - & - \\
\hline 93. Length (feet) & - & - & - & - \\
\hline 94. \# of piles & pro- & & - & - \\
\hline 95. Cross-members & tec- & & - & - \\
\hline 96. Scour Condition & tion & & - & - \\
\hline 97. Scour depth & were & & - & - \\
\hline 98. Exposure depth & scat- & & - & - \\
\hline
\end{tabular}

LFP, LTB, LB, MCL, MCM, MCR, RB, RTB, RFP

1- Solid pier, 2- column, 3- bent

1-Wood; 2-concrete; 3- metal; 4- stone

1- Round; 2- Square; 3- Pointed

Y-yes; $N$ - no

$L B$ or $R B$

0- none; 1- laterals; 2- diagonals; 3- both

0- not evident; 1- evident (comment);

2- footing exposed; 3- piling exposed;

4- undermined footing; 5- settled; 6- failed 
99. Pier comments (eg. undermined penetration, protection and protection extent, unusual scour processes, etc.):

-
-
-
-
-
-
-
-
-
-

100.

\section{E. Downstream Channel Assessment}

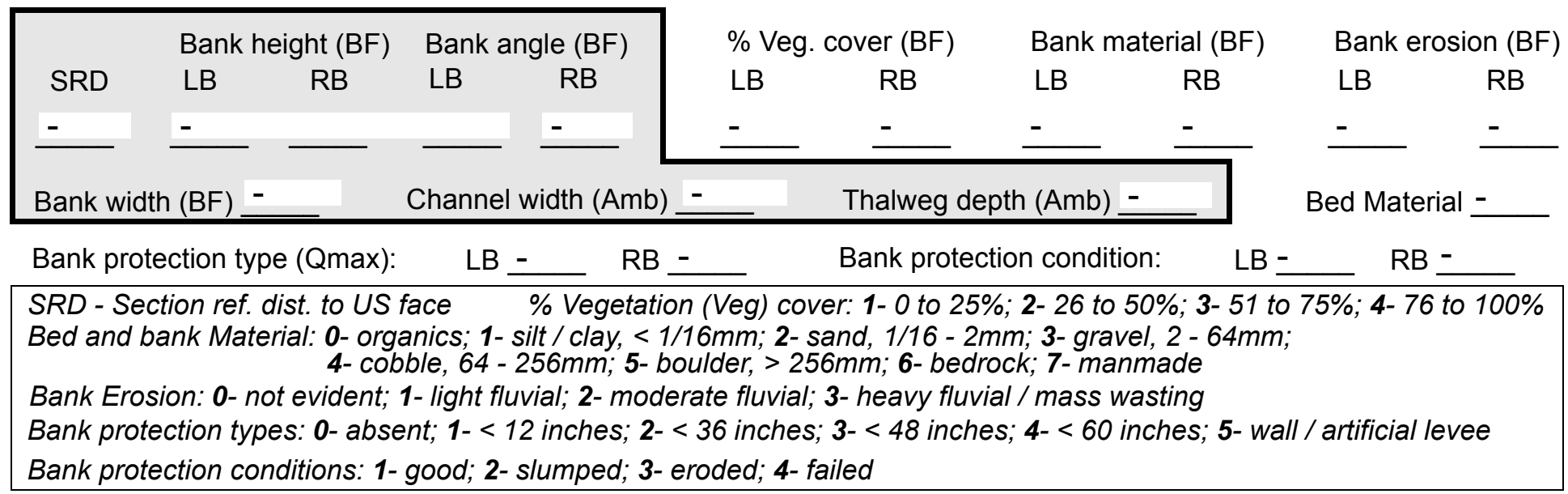

Comments (eg. bank material variation, minor inflows, protection extent, etc.):

-
-
-
-
-
-
-
-

NO PIERS

101. Is a drop structure present? ( $Y$ or $N$, if $N$ type ctrl-n ds)

102. Distance: - feet

103. Drop: - feet 104. Structure material: (1- steel sheet pile; 2- wood pile; 3- concrete; 4- other)

105. Drop structure comments (eg. downstream scour depth): 
106. Point/Side bar present? 0 ( $Y$ or $N$. if $N$ type ctrl-n pb)Mid-bar distance: $\mathbf{0}$

Mid-bar width: 3

Point bar extent: $\underline{\mathbf{0}}$ feet 0

(US, UB, DS) to feet (US, UB, DS)

DS) positioned $\underline{\mathbf{T h}}$ $\%$ LB to $\%$ RB

Material: ba

Point or side bar comments (Circle Point or Side; note additional bars, material variation, status, etc.):

nk material again is organics overlying cobbles and boulders. The bed material ranges from mostly coarse gravel to some cobbles and boulders.

Is a cut-bank present? (Y or if $N$ type ctrl-n cb) Where? (LB or $R B)$

Mid-bank distance:

Cut bank extent: feet (US, UB, DS) to feet (US, UB, DS)

Bank damage: (1- eroded and/or creep; 2- slip failure; 3- block failure)

Cut bank comments (eg. additional cut banks, protection condition, etc.):

$\mathbf{N}$

Is channel scour present? _ _ (Y or if N type ctrl-n cs) Mid-scour distance: NO

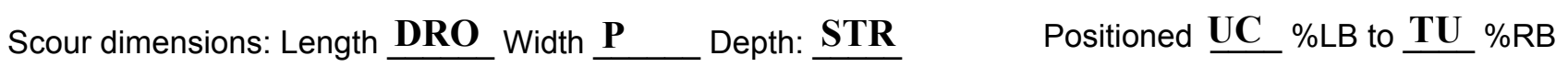
Scour comments (eg. additional scour areas, local scouring process, etc.):

RE

Are there major confluences?

Confluence 1: Distance $\underline{\mathbf{Y}}$
Confluence 2: Distance $\underline{\mathbf{1 0}}$

Confluence comments (eg. confluence name):

DS

70 ( $Y$ or if $N$ type ctrl-n $m c$ ) Enters on $\underline{\mathbf{0}}$ ( $L B$ or $R B)$ Enters on $\underline{\mathbf{U B}}$ ( $L B$ or RB)
How many?

Type 10.0 (1- perennial; 2- ephemeral) Type 25 (1- perennial; 2- ephemeral)

\section{F. Geomorphic Channel Assessment}

107. Stage of reach evolution

1- Constructed

2- Stable

3- Aggraded

4- Degraded

5- Laterally unstable

6- Vertically and laterally unstable 
108. Evolution comments (Channel evolution not considering bridge effects; See HEC-20, Figure 1 for geomorphic descriptors):

4

Point bar material ranges from sand to boulder size. The boulders appear remnants of riprap protection.

$\mathbf{N}$

$-$

$-$

$-$

$-$

$-$

-

- 


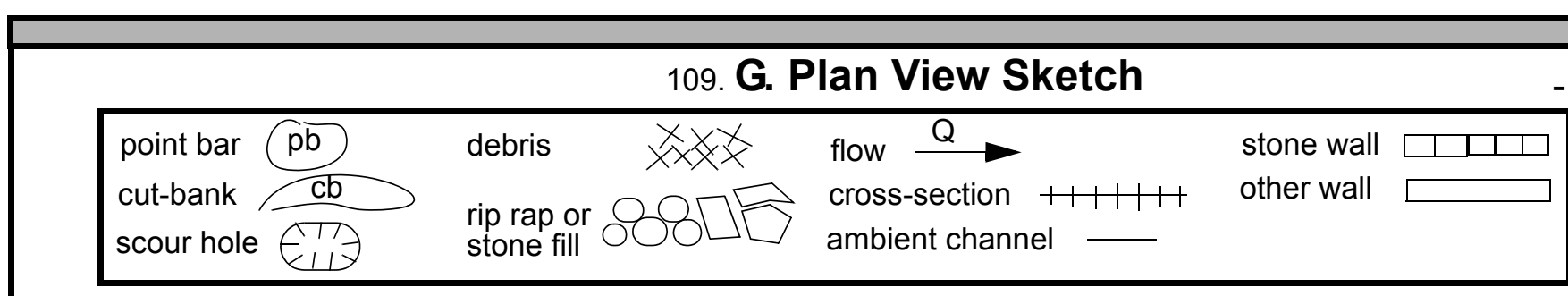


APPENDIX F:

SCOUR COMPUTATIONS 


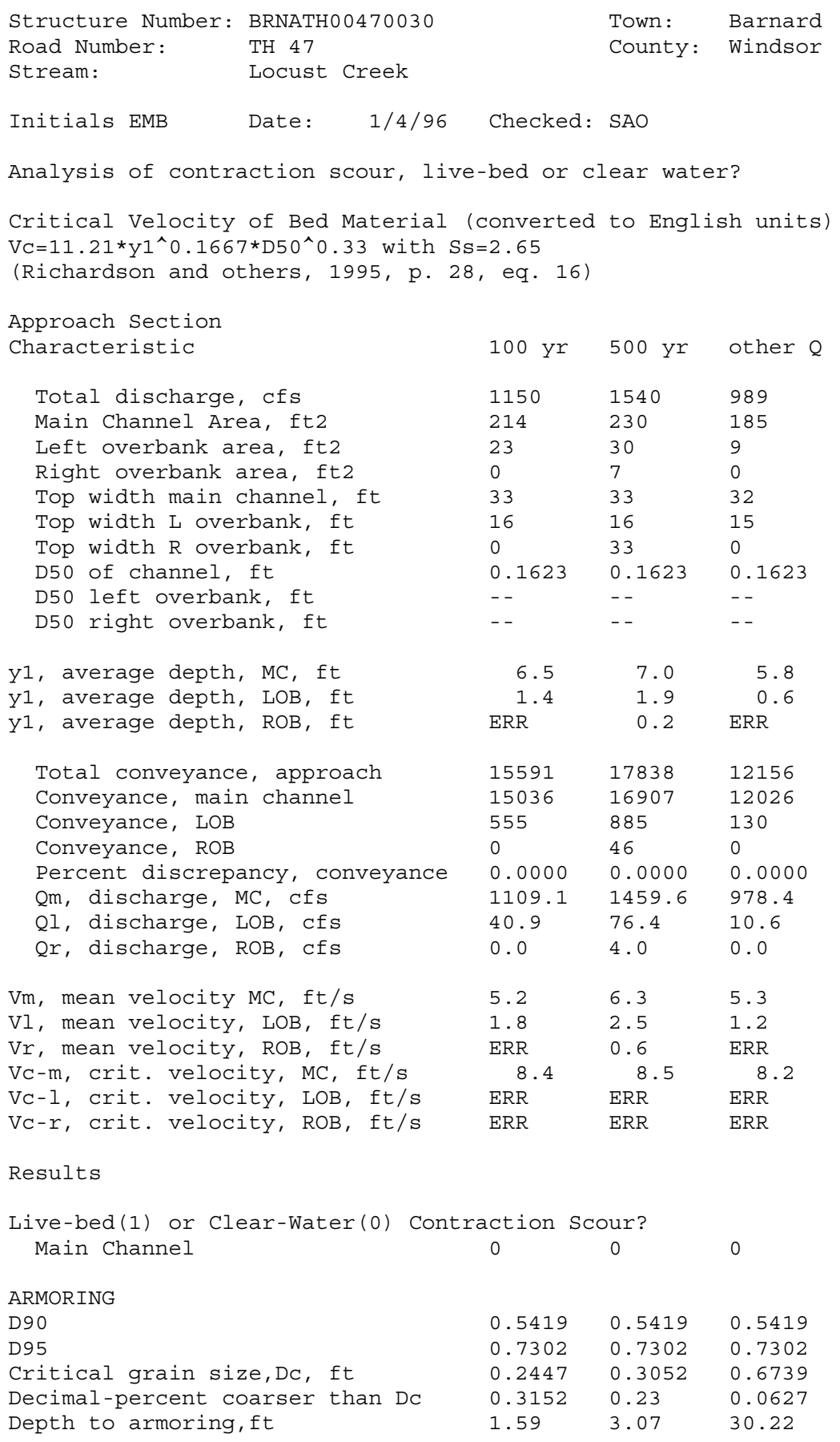


Clear water Contraction Scour in MAIN CHANNEL

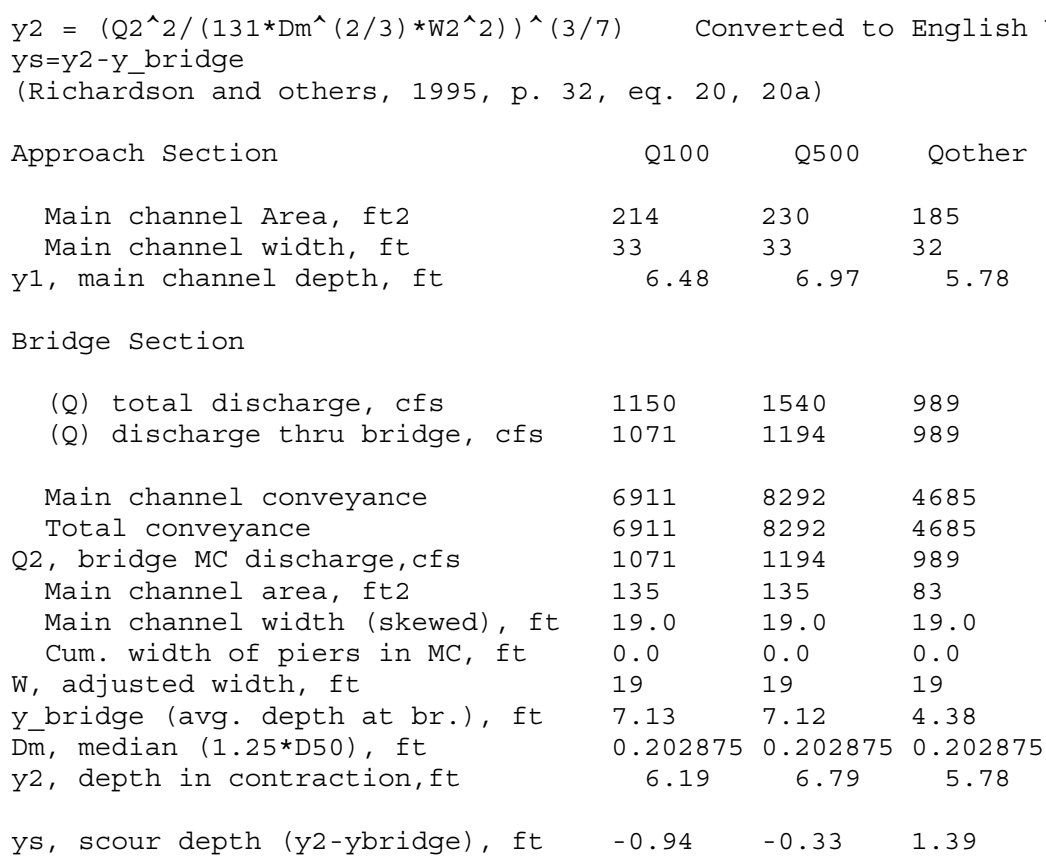

Pressure Flow Scour (contraction scour for orifice flow conditions)

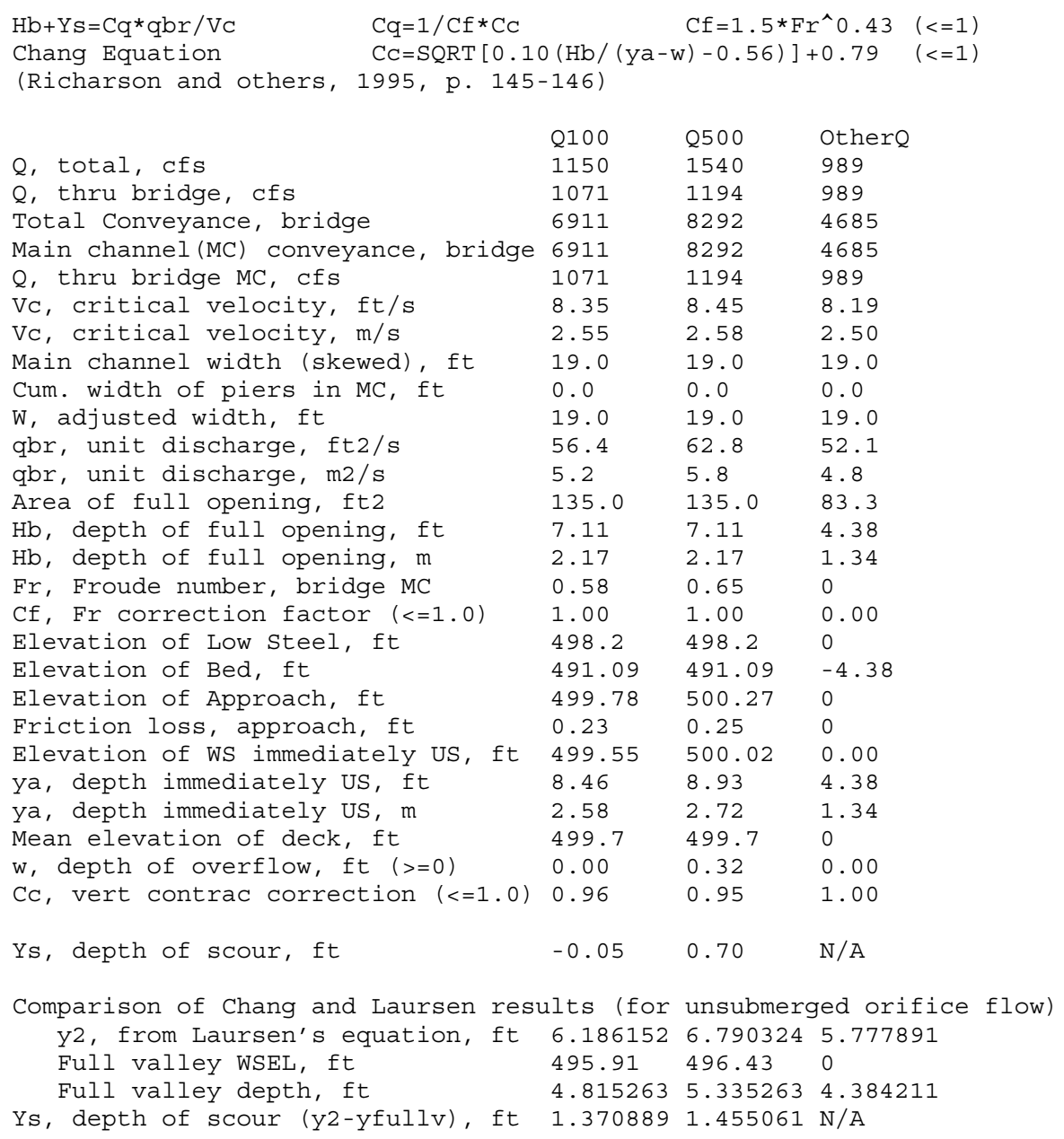




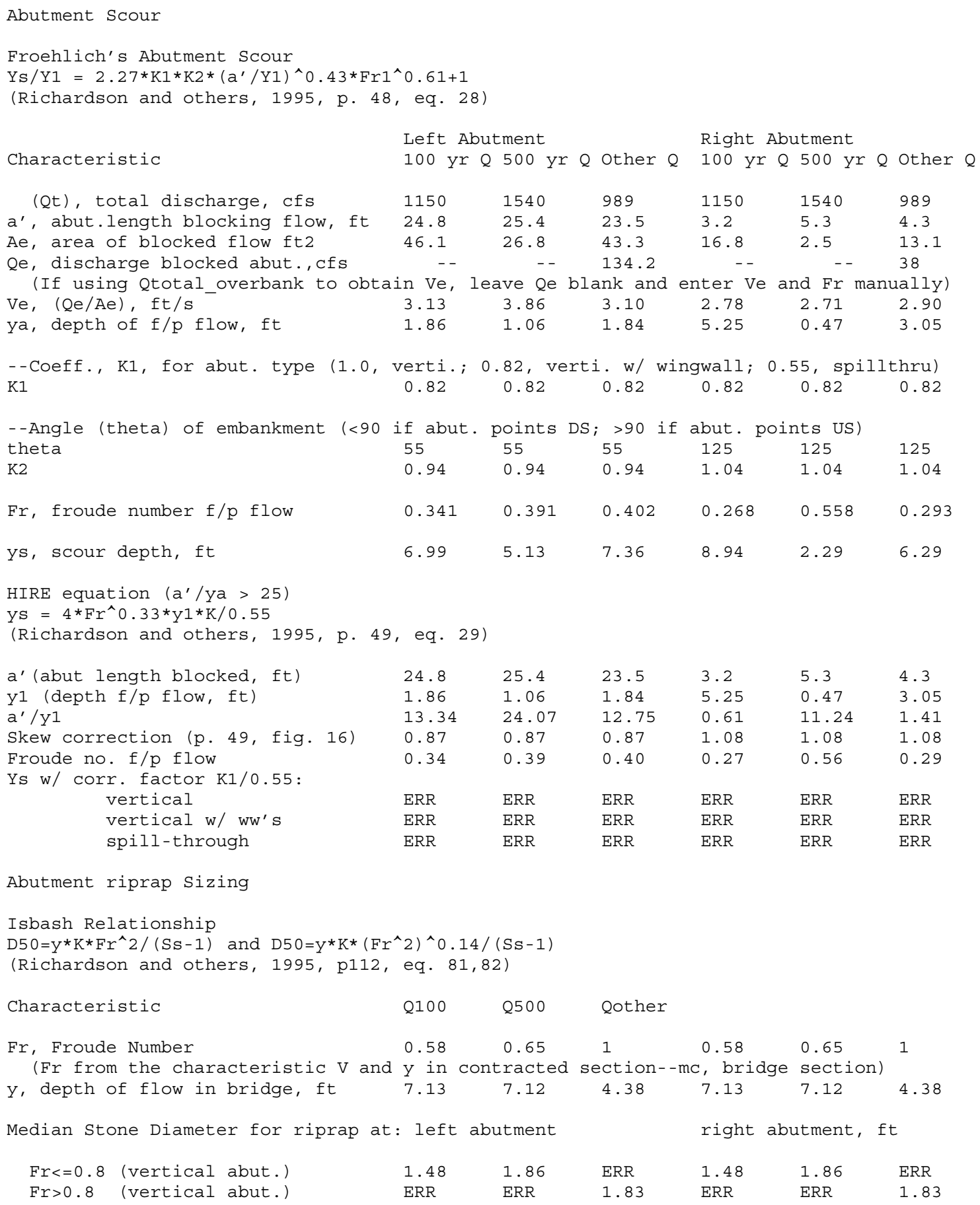

